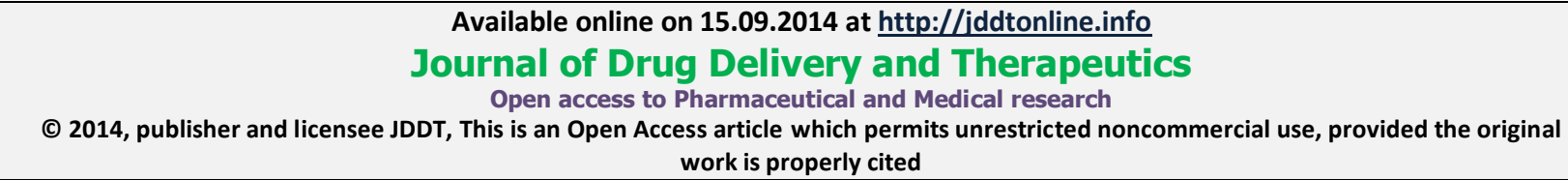

\title{
MONOGRAPHIC STUDY OF PLANT SPECIES MOST USED FOR TREATMENT OF COMMON DISEASES OF SOMBA CATTLE IN BENIN
}

\author{
Tiropa Francis CHABI CHINA ${ }^{1 *}$, Pascal Abiodoun OLOUNLADE ${ }^{2}$, Sahidou SALIFOU ${ }^{3}$ \\ ${ }^{1}$ Faculté des Sciences Agronomiques, Université d'Abomey-Calavi, 01 BP 526 Cotonou, Bénin \\ ${ }^{2}$ Laboratoire Pluridisciplinaire, Ecole Nationale Supérieure des Sciences et Techniques Agronomiques de Kétou, \\ Université d'Agriculture de Kétou BP: 95 Kétou, Bénin
}

${ }^{3}$ Ecole Polytechnique d'Abomey-Calavi, Université d'Abomey-Calavi, Département de Production et de Santé Animale. BP: 2009 Cotonou, Bénin

*Corresponding author: tiropaacc@yaho.fr

\begin{abstract}
To face the common ailments of Somba cattle in it natural area, some breeders use endogenous methods based herbal. The present study is a monography of the most used plants in order to appropriate all the literature that exists on these plants before eventually begin experimental studies for scientific validation of their therapeutic effects. For each plant species, the study examined the following data: the botanical description, geographical and ecological distribution, chemical composition, pharmacological uses, and other uses. It basically shows that the study of medicinal uses mentioned by the Somba cattle plants are widely reported by many other authors in various African, Asian and Latin American countries, but much more in human medicine than in veterinary medicine. The predominance of compounds pharmacological properties reported in the chemical compositions by different studies also confirmed the therapeutic capabilities of these plants. By cons, very few of the pharmacological and therapeutic properties have been described scientifically proven.
\end{abstract}

Keywords: monography-plants-diseases-somba cattle

\section{INTRODUCTION}

The Somba cattle breed is a pure breed (Adanléhoussi et al., 2003) whose range is very small. This breed only found in the region between the north-west of Benin and the north-eastern Togo (Dossa, 2000). The Somba cattle breed is now endangered due to a drastic and continuous decrease of it herds (Dossa, 2000; PAMRAD, 2006; Sokouri et al., 2010).

These authors whose have worked on this race index absorption by the zebu as the basis for the regression. But in a recent study on zootechnical parameters of Somba cattle, China Chabi et al. (2013) reveal a very high mortality of $16 \%$ on average in herds with a large contribution of calves and calfs at this rate, and that this mortality is following to the absence of health monitoring cattle. What would be the basis of the regression. The influence of zebu is currently marginal because $96.22 \%$ of cattle at the farm level respondents are Somba breed (PAMRAD 2006; Chabi China et al, 2013).

The high cost of veterinary care and lack of veterinary agents are the main reasons given by farmers to justify the bad health management of their livestock. However, many of them expressed an awareness and use of alternative methods including endogenous practices of bovine diseases treatment based on plants.

In order to enhance these endogenous methods to contribute to significant reduction of mortality we have undertaken in a previous study to identify all these methods and medicinal recipes through an ethnobotanical survey (Chabi China et al., 2014). At the end of this study, we identified 11 plant species from all plants listed as the most widely used for the treatment of common ailments of Somba cattle.

These 11 plant species will be tested experimentally in future studies to scientifically verify their effectiveness in the indicated conditions. This is a prelude to the future work that we decided to make the monographic study of each of these plants to know them better and find out what has already been achieved as work on these plants including animal health. 


\begin{tabular}{|c|c|c|c|}
\hline $\begin{array}{lll}\begin{array}{l}\text { Botanical } \\
\text { distribution }\end{array} & \text { description } & \text { and } \\
\end{array}$ & Phytochemistry & Pharmacological uses & Other uses \\
\hline & & & \\
\hline $\begin{array}{l}\text { The baobab is a massive deciduous } \\
\text { tree easily distinguishable by its huge } \\
\text { trunk. It is regarded as the largest } \\
\text { succulentplant in the world with a } \\
\text { diameter of } 10-12 \mathrm{~m} \text { and a height of } \\
23 \text { m or more (Wickens, 1982; } \\
\text { Chadare et al., 2009). } \\
\text { The baobab is found in many African } \\
\text { countries. Eight baobab species have } \\
\text { been identified globally and six } \\
\text { species found on the island of } \\
\text { Madagascar are endemic to that } \\
\text { region (Wickens and Lowe, } 2008 \text { ). It } \\
\text { is postulated that the centre of } \\
\text { evolutionary origin of the genus } \\
\text { Adansonia is Madagascar (Drake, } \\
2006 \text { ). The African species A. } \\
\text { digitata is indigenous to, and widely } \\
\text { distributed throughout the savannas } \\
\text { and savanna woodlands of sub- } \\
\text { Saharan Africa (Wickens and Lowe, } \\
\text { 2008). } \\
\text { Baobab is restricted to hot, semi-arid } \\
\text { regions, dry woodland and stony } \\
\text { places with low rainfall (less than } \\
1500 \text { mm annually) (Gebauer et al., } \\
2002 \text { ) and grows on a wide range of } \\
\text { well-drained soils, from clays to } \\
\text { sands, but not on deep } \\
\text { unconsolidated sands, where it is } \\
\text { unable to obtain sufficient moisture } \\
\text { or anchorage (Wickens and Lowe, } \\
2008 \text { ). In Africa, the plant grows at a } \\
\text { latitude of } 16^{\circ} \mathrm{N} \text { and } 26^{\circ} \mathrm{S} \text { in areas } \\
\text { not receiving more than one day of }\end{array}$ & 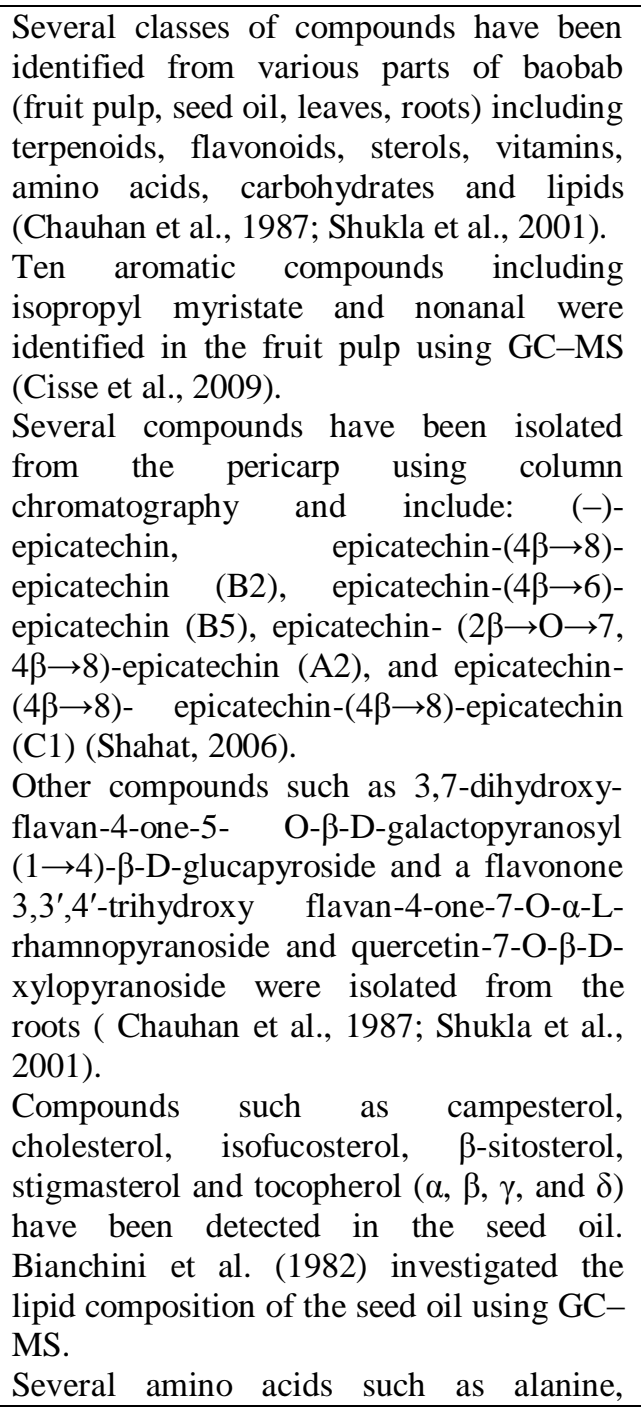 & $\begin{array}{l}\text { - Leaves, bark and seeds are used in } \\
\text { the treatement of malaria, tuberculosis, } \\
\text { fever, microbial infections, diarrhoea, } \\
\text { anaemia, dysentery, toothache, etc. } \\
\text { (Van Wyk and Gericke, 2000; } \\
\text { Brendler et al., 2003; Tapsoba and } \\
\text { Deschamps, 2006; Wickens and Lowe, } \\
\text { 2008; De Caluwé et al., 2009; Nguta et } \\
\text { al., 2010). } \\
\text { - The fruit pulp is used in the treatment } \\
\text { of diarrhoea and dysentery, painful } \\
\text { swellings, internal pains, urinary } \\
\text { deases, otitis, as a tonic and for insect } \\
\text { bites and Guineaworms (young leaves) } \\
\text { (Sidibe and Williams, 2002). } \\
\text { - The leaves are used as insect } \\
\text { repellent (Denloye et al.,2006). } \\
\text { - Substitute for quinine to relievefever } \\
\text { (bark) (Shukla et al., 2001). } \\
\text { - Against diarrhoea and hiccough (oil } \\
\text { extrated from the seeds) (De Caluwé et } \\
\text { al.,2009). }\end{array}$ & $\begin{array}{l}\text { - For rope-making (bark) (De Caluwé et al., } \\
\text { 2009). } \\
\text { - To store water (trunk) (Royal Botanic } \\
\text { Gardens, Kew, 1999). } \\
\text { - For several purposes including: fruit for } \\
\text { food; oil from the seeds; rope, cordage and } \\
\text { cloth from the bark fibre; tannin for curing } \\
\text { leather from the tree bark; glue from the } \\
\text { pollen grain of the flowers; pulp for making } \\
\text { paper from the harvested tree (although of } \\
\text { low quality), seasoning and as an appetiser } \\
\text { (Wickens, 1982; Sidibe and Williams, 2002; } \\
\text { Nhukarume et al., 2008). } \\
\text { - For the production of vegetable oil } \\
\text { (Bianchini et al., 1982). } \\
\text { - For cooked and ingredient in sauces, } \\
\text { porridges and beverages (leaves, fruit pulp } \\
\text { and seeds) (Chadare et al., 2009; De Caluwé } \\
\text { et al., 2009; Yusha'u et al., 2010). } \\
\text { - To treat skin ailments, thus it may have } \\
\text { some cosmetic applications (oil extrated from } \\
\text { seeds) (Sidibe and Williams, 2002). } \\
\text { - Ingredients in cosmetic products and } \\
\text { amongst these is baobab seed oil. It is } \\
\text { suitable for use on the skin as it is non- } \\
\text { irritating and non-allergenic (fixed oil) (Wren } \\
\text { and Stucki, 2003). Other properties of } \\
\text { pharmaceutical/cosmetic importance include } \\
\text { that it is excellent for restoring and } \\
\text { remoisturising the skin due to its high } \\
\text { penetrability and nourishing properties. It can } \\
\text { also be used to treat eczema and psoriasis } \\
\text { (PhytoTrade Africa). } \\
\text { - As a protecting, nourishing, moisturising, } \\
\text { soothing and regenerating agent (oil of seeds) }\end{array}$ \\
\hline
\end{tabular}




\begin{tabular}{l|l}
$\begin{array}{l}\text { frost per year. The tree grows very } \\
\text { slowly probably due to low amount } \\
\text { of rainfall received (Venter and } \\
\text { Venter, 1996). }\end{array}$ & $\begin{array}{l}\text { arginine, glycine, lysine, methionine, } \\
\text { proline, serine, valine (from fruit pulp) } \\
\text { (Glew et al., 1997), vitamins (B1, B2, B3, }\end{array}$ \\
$\begin{array}{l}\text { A, C) (from fruit pulp and/or leaves) } \\
\text { (Sidibe et al., 2002; UNCTAD, 2005) and }\end{array}$ \\
minerals (Cu, Fe, K, Mg, Mn, Na, P, Zn) \\
(from fruit pulp) (Glew et al., 1997) have \\
also been identified.
\end{tabular}

\section{Afzelia africana}

Afzelia african is an evergreen, small to fairly large tree up to $40 \mathrm{~m}$ tall. Bole branchless for up to $20 \mathrm{~m}$, usually straight and cylindrical, up to $150(-200) \mathrm{cm}$ in diameter, often with unequal, thick buttresses up to $1.5 \mathrm{~m}$ high. The bark surface greyish to reddish brown, scaly with roundish scales, inner bark pale brown to pinkish brown, with yellowish brown exudate, very aromatic (OtengAmoako, 2006; Hawthorne and Jongkind, 2006).

Afzelia africana is characteristic for the transition zone between wooded savanna and dense dry forest, and for dense semi-deciduous forest in more humid regions. Afzelia africana shows a wide adaptation to climatological conditions, but is most common in areas with an annual rainfall of more than $900 \mathrm{~mm}$. In drier regions it is limited to localities with deep, well-drained but moist soils and to termite mounds. It occurs up to $1400 \mathrm{~m}$ altitude Afzelia africana is found on a wide variety of soil types, often on
- The seeds have high carbohydrate, crude oil and protein contents and are therefore rich sources of energy, dietary lipid and protein (Ejikeme et al., 2010)

The seeds contain about $27 \%$ protein, $33 \%$ carbohydrate and $32 \%$ lipid. They contain $18-37 \%$ of oil. Linoleic acid is the predominant fatty acid. Toxicological studies of the oil showed no detectable toxins. The presence of a cyanogenic compound may explain the reputed toxicity of the seed (Bationo et al., 2001 ; Kock et al., 2006; Sakande, 2007).

- The seeds oil was found to contain no less than $0.60 \mathrm{mg} / 100 \mathrm{~g}$ of oxalate, $0.70 \mathrm{mg} / \mathrm{kg}$ cyanogenic glycosides (Ejikeme et al., 2010).

- The leaves was found to contain high level of crude protein, nitrogen, gross energy, calcium, phosphorus, potatium, and sodium (Ikhimioya and Imasuen, 2007). of phytate and neither tannins or
- Root decoctions or macerations are used to treat stomach complaints, convulsions, trypanosomiasis and hernia, and as antidote. Root powder is applied externally to treat rheumatism (Burkill, 1995; Neuwinger, 2000 Oteng-Amoako, 2006 ).

- Bark decoctions and macerations are administered in the treatment of constipation, fever, vomiting, oedema tachycardia, hypertension, bronchitis, lung complaints and bleedings during pregnancy, and as anodyne, diuretic, galactagogue and aphrodisiac. Bark ash is applied externally to trea lumbago and bark powder to wounds and swellings. The stem bark is used against trypanosomiasis, and bacteria (Neuwinger, 2000; Atawodi et al., 2002 ; Magassouba et al., 2007).

- Leaves decoctions and maceration are taken or applied externally against dysmenorrhoea, epilepsy, oedema, migraine, stomach-ache, asthenia, trypanosomiasis and as anodyne (Burkill, 1995 ; Neuwinger, 2000

Magassouba et al., 2007).

- Fruit preparations are taken to treat
(Nkafamiya et al., 2007)

- The wood is also valued for joinery and panelling, both interior and exterior, parquet floors, doors, frames, stairs, furniture and sporting goods. It has been used traditionally for canoes. It is commonly used for domestic articles such as boxes, bowls, spoons, mortars and masks, and is locally popular for making drums. The wood is also used as firewood and for charcoal production.

- The foliage is commonly used as forage and the tree is particularly important as a source of fodder for livestock in the dry season. The leaves are sometimes eaten cooked as a vegetable (Aye and Adeyey, 2002).

- The fruits have been used as castanets, seeds for necklaces and for other ornamental purposes. Fruit preparations are taken as aphrodisiac. Fruit ash is uses as soap substitute.

- The flowers are used as condiment in sauces.

- The bark is used as fish poison.

- The roots have been used in mixtures to prepare arrow poison.

- Twigs are used as chewing sticks.

(Normand and Paquis, 1976 ; Burkill, 1995 ;

Loupe, 2000 ; Arbonier, 2004 ; Hawthorne and Jongkind, 2006 ; Sakande, 2007 ; Orwa 


\begin{tabular}{|c|c|c|c|}
\hline $\begin{array}{l}\text { hardpans of calcareous, sandy or } \\
\text { ferralitic soils, on steep slopes, as } \\
\text { well as in depressions and in } \\
\text { regularly inundated sites } \\
\text { (Neuwinger, 2000; Arbonier, 2004; } \\
\text { Oteng-Amoako, 2006; Orwa et al., } \\
2009 \text { ). }\end{array}$ & & $\begin{array}{l}\text { lung complaints. Fruit ash is applied } \\
\text { against leprosy (Neuwinger, 2000). }\end{array}$ & 2009). \\
\hline \multicolumn{4}{|l|}{ 3. Bridelia ferrugina } \\
\hline $\begin{array}{l}\text { Bridelia ferruginea Benth. } \\
\text { Euphorbiaceae is a shrub commonly } \\
\text { growing up to a height of } 45 \text { feet in } \\
\text { the Savannah or in open spaces of } \\
\text { coastal districts (Ngueyem et al., } \\
\text { 2009). The genus Bridelia includes } \\
\text { approximately 60-70 species, from } \\
\text { Africa to Asia. (Kathriarachchi et al., } \\
\text { 2005; Ngueyem et al., 2009). }\end{array}$ & $\begin{array}{l}\text { Chemical analysis found the bark to } \\
\text { contain potassium, sodium, calcium, } \\
\text { magnesium, zinc, manganese, iron and } \\
\text { copper. Phytochemical tests revealed } \\
\text { the bark to contain tannins, } \\
\text { phlobatannins, saponins, alkaloids, and } \\
\text { steroids (Kolawole al., 2007). } \\
\text { The phytochemical screening of B. } \\
\text { ferruginea leaves showed the presence } \\
\text { of coumarins, anthracenic derivates, } \\
\text { flavonoids, essential pigments, } \\
\text { naphtoquinones, } \\
\text { triterpenoids and tannins (Lagnika et } \\
\text { al.,2012). } \\
\text { The flavonoids gallocatechin-(4-O-7 } \\
\text { epigallocatechin), } \\
\text { methylether, 3,5-dicaffeoylquinic acid, } \\
\text { quercetin 3,7,3,4-tetramethylether, } \\
\text { myricetin and quercetin 3-O-glucoside } \\
\text { have been isolated from extracts of } \\
\text { Bridelia ferruginea (Cimanga et 2001; } \\
\text { De-Bruyne et al., 1998). }\end{array}$ & $\begin{array}{l}\text { - The stem bark is used to treat epilepsy, } \\
\text { oedemas, irritability of the infant, } \\
\text { gastralgias, anaemia, dysenteria and } \\
\text { rheumatisms (Adjanohoun et al., 1989) and } \\
\text { as anti inflamatory (Fujii et al., 2000; } \\
\text { Wada et al., 2000; Olajide et al., 2003; } \\
\text { Olumayokun et al., 2003). } \\
\text { - The poultice of the leaves are applied to } \\
\text { wounds, open cuts, and sores (Adetutu et } \\
\text { al., 2011) } \\
\text { - The leaves are also used as nematicide } \\
\text { (Fabiyi et al., 2012), and as antibacterial } \\
\text { (Magassouba et al., 2007). } \\
\text { - The leaves, bark and fruits are used for the } \\
\text { treatment of dysentery, diabetes, } \\
\text { rheumatism pains, intestine disorders, } \\
\text { epilepsy, infectious diseases, including } \\
\text { sexually transmitted diseases, skin diseases } \\
\text { and eruption, skin cancer, cystitis, } \\
\text { roundworm (anthelmintic) Akinpelu and } \\
\text { Olorunmola, 2000; Cimanga et al., 2001). } \\
\text { It's also used as anti-arthritic, antipyretic, } \\
\text { analgesicas and as antidote for arrow } \\
\text { poison, (Olajide et al., 2000; Ngueyen et } \\
\text { al., 2009) and as antitumor (Rhashid et al., } \\
\text { 2000). } \\
\text { - The root decoction is also used for the } \\
\text { treatment of gonorrhoea (Irobi et al., 1994; } \\
\text { akinpelu and Olorunmola). }\end{array}$ & $\begin{array}{l}\text { - The leaves of Bridelia ferrugina are use as } \\
\text { forage for sheep and cattle (Alade et al., } \\
\text { 2010). } \\
\text { - The bark extract of the plant has been used } \\
\text { for the coagulation of milk and also lime } \\
\text { juice for the formulation of a traditional } \\
\text { gargle (Orafidiya et al., 1990). } \\
\text { - The roots of the plant are used as chewing } \\
\text { sticks (De-Bruyne et al., 1998). }\end{array}$ \\
\hline
\end{tabular}




\begin{tabular}{|c|c|c|c|}
\hline 4. Carica papaya & & & \\
\hline $\begin{array}{l}\text { Carica papaya } \\
\text { (Caricaceae) is a fast- } \\
\text { growing, semiwoody tropical } \\
\text { tree reaching } 3-10 \mathrm{~m} \text { in } \\
\text { height. The fleshy stem is } \\
\text { single, straight and hollow } \\
\text { and contains prominent leaf } \\
\text { scars. Papaya exhibits strong } \\
\text { apical dominance rarely } \\
\text { branching unless the apical } \\
\text { meristem is removed, or } \\
\text { damaged. (Zunjar et al., } \\
\text { 2011; Milind and Gurditta, } \\
\text { 2012). }\end{array}$ & $\begin{array}{l}\text { The phytochemical screning of extractof the Carica } \\
\text { papaya fruit pulp was and found to contain alkaloids } \\
\text { (carpaine, pseudocarpaine, carpesamine), saponins, } \\
\text { phenolic compounds, ferulic acid, chlorogenic acid, vanillic } \\
\text { acid), tannins, phlobatannins, flavonoids (kaempferol, } \\
\text { quercetin, rutin) and terpenoids (Krishna et al., 2008; } \\
\text { Gurung and Shalko, 2009; Kabebew and Shibeshi, 2013; } \\
\text { Varisha et al., 2013). } \\
\text { About the content of total carotenoids in papaya fruit pulp } \\
\text { the studies revealed that the major carotenoids found in } \\
\text { papaya were lycopene, } \beta \text {-cryptoxanthin, and } \beta \text {-carotene, } \\
\text { with lycopene representing 65\% of the total. (Marelli de } \\
\text { Souza et al., 2008; Andersson et al., 2009; Rivera-Pastrana } \\
\text { et al., 2010; Yahia and Ornelas-Paz, 2010; Gayosso- } \\
\text { García Sancho et al., 2011; Varisha et al., 2013). } \\
\text { The mineral composition of fruit pulp revealed a high level } \\
\text { of calcium, phosporus, sodium and potatium. } \\
\text { About vitamin contents, the fruit pulp screening shown the } \\
\text { presence of thiamine, vitamin C, niacin and riboflavin } \\
\text { (Nwofia and Okwu, 2012; Varisha et al., 2013). } \\
\text { The phytochemical screning of the others parts of papya } \\
\text { are: } \\
\text { - The seeds : carpaine, benzyl-isothiocyanate, benzyl- } \\
\text { glucosonialate, benzyl-thiourea, } \\
\text { hentriacontane, B-sytosterol, caricin and enzyme myrocin. } \\
\text { - The leaves : alkaloids carpain, pseudocarpin and } \\
\text { dehydrocarpaine I and II, choline, carposide, vitamin C and } \\
\text { E. } \\
\text { - The root : carposide and enzyme myrocin. } \\
\text { - The bark: B-sytosterol, glucose fructose, sucrose, } \\
\text { galactose, and xylitol. } \\
\text { - The latex : proteolytic enzymes, papain and chemopapain, } \\
\text { glutamine cyclotransferase, chymopapain A, B and C, } \\
\text { peptidase A and B, and lysozymes. } \\
\text { (Krishna et al., 2008; Gurung and Shalko, 2009; Zunjar et } \\
\text { al., } 2011 \text {; Kabebew and Shibeshi, 2013). }\end{array}$ & $\begin{array}{l}\text { Different parts of Carica papaya have } \\
\text { been used traditionally to treat various } \\
\text { ailments in humans and animals across } \\
\text { the world: } \\
\text { - The seeds are used as contraceptive } \\
\text { (Lohiya et al., 2000; Goyal et al., 2010) } \\
\text { and can produces marked uterine } \\
\text { contractions (Anuar et al., 2008; } \\
\text { Abdulazeez et al., 2009). The seeds are } \\
\text { also used as anthelmintic, anti-tumor, } \\
\text { antimicrobial, antimalarial, and } \\
\text { antioxidant (Stepek et al., 2005; Gurung } \\
\text { and Skalko, 2009; Otsuki et al., 2010). } \\
\text { - The pulp is used as sedative and } \\
\text { anxiolitic (Wang et al., 2007; Krishna et } \\
\text { al., 2008; Blainski et al., 2010; } \\
\text { Hajhashemi et al., 2010; Tovilovic et } \\
\text { al., 2011; Kabebew and Shibeshi, } \\
\text { 2013). } \\
\text { - The green unripe fruit is used as } \\
\text { remedy for ulcer, impotence as an } \\
\text { antiseptic, as diuretic, } \\
\text { hepatoprotective, as laxative, and as } \\
\text { antidote to snake bite. The milky juice of } \\
\text { the green unripe fruit is used as remedy } \\
\text { in dyspepsia, kindred deases, and in the } \\
\text { treatment of gangerous wounds (Hewitt } \\
\text { et al., 2000; Bouanga-Kalou et al., } \\
\text { 2011; Nwofia and Okwu, 2012). } \\
\text { - The ripe fruit has been used as } \\
\text { digestive, anti-diarrhoeal, expectorent, } \\
\text { sedative, anti-obesity and psoriasis } \\
\text { (Cherian, 2000; Adeneye and Olagunju, } \\
\text { 2009; Varisha et al., 2013). }\end{array}$ & $\begin{array}{l}\text { - The ripe papaya is a favourite } \\
\text { breakfast and dessert fruit that is } \\
\text { available year-round. It can be } \\
\text { used to make fruits salads, } \\
\text { refreshing drinks, jam, jelly, } \\
\text { marmalade, candies and } \\
\text { crystallized fruit. Green fruit is } \\
\text { pickled or cooked as vegetable or } \\
\text { as a substitute for apple sauce } \\
\text { (Latham, 2004; Janick and Paull, } \\
\text { 2006). } \\
\text { - The green unripe fruit juice is the } \\
\text { main source of papain (a } \\
\text { proteolytic enzyme) extraction. } \\
\text { Papain has varied uses in } \\
\text { beverage, food, in chill-proofing } \\
\text { beer, tenderizing meat. It is also } \\
\text { used in bathing hides, degumming } \\
\text { silk and softening wool. (Bouanga- } \\
\text { Kalou et al., 2011; Varisha et al., } \\
\text { 2013). } \\
\text { - Carica papaya has also been used } \\
\text { as animal food or feed. The leaves } \\
\text { have been used for minerals, } \\
\text { vitamins (Janick and Paull, 2006). }\end{array}$ \\
\hline
\end{tabular}




\section{Entada africana Guill. \& Perr.}

Entada africana is a small tree up to $4-10 \mathrm{~m}$ in height and $90 \mathrm{~cm}$ in girth. The branching low down, with a wide crown. The bark brown-grey to black, very rough, transversely striped, scaly, peeling in long fibrous strips, slash fibrous, red or yellow-brown.

E. africana grows in high rainfall savannah areas. Trees are found in the Sudan zone, only exceptionally penetrating into the southern Sahel. It occurs on the lower slopes or banks of swamps, on ground water sites. It is very sensitive to bush fires, often mutilated by it (Arbonnier, 2000 ; Taïta, 2000 ; Diallo et al., 2001 ; Pousset, 2004).

\section{Biophysical limit}

- Mean annual rainfall: 600-1 $200 \mathrm{~mm}$;

- Mean annual temperature: $20-32^{\circ} \mathrm{C}$

- Altitude: 200-1 500m ;

- Deep sandy soils; rocky soils.

(Arbonnier, 2000 ; Neuwinger, 2000 ; Pousset, 2004)
The phytochemical analysis revealed the presence of phenolic compounds, tannins, flavonoids, coumarins, and anthocyans, as major principle components of differents part of the plant (Almela et al. 2006; Tibiri et al. 2007 ; Mariani et al., 2008; AbdelHameed, 2009 ; Arcan and Yamenicioglu, 2009 ; Tibiri et al., 2010).

The phyotchemical screnning revealed also that $\mathrm{E}$. africana was rich in terpenic and steroidic components (Sterols, triterpenes, and saponins) (Coffi et al., 2006; Tibiri et al., 2010)
The stem, roots, trunk bark, leaves, fruits, and plant gum are used :

- Against malaria (Silva et al., 1996; Bah, 1998 ;Atindehou et al., 2004 ; Koné et al., 2004).

- As antileishmanial (Ahua et al., 2007).

- As anti-inflammatory, hepato-protective, woundhealing, and haemostatic (Sanogo et al., 1998; Diallo et al., 2001 ; Inngjerdongen et al., 2004).

- Against respiratory deases (Silva et al., 1997 ; Neuwinger, 2000 ; Koné et al., 2004 ; Magassouba et al., 2007).

- Against diabete, hypertension, and diarrhoea (Nacoulma-Ouédraogo et al., 1996 ; Sanogo et al. 1998 ; Nacoulma-Ouédraogo and MillogoRasolodimby, 2002 ; Pousset, 2004).

As fortifuer, diuretic, anti-gonococci, antisyphilitic, abortifacient, antipyretic, and antirheumatism (Burkill, 1995; Neuwinger, 2000 Atawodi et al., 2004 ; Tibiri et al., 2007).
6. Khaya senegalensis

Khaya senegalensis is a deciduous evergreen tree, $15-30 \mathrm{~m}$ high, up to 1 $\mathrm{m}$ in diameter, with a clean bole to 8 $16 \mathrm{~m}$, buttresses not prominent or absent; bark dark grey, with small, thin, reddish-tinged scales; slash dark pink to bright crimson, exuding a red sap (FAO, 1986; Katende et al. 1995; Sosef et al., 1998)

$\mathrm{K}$. senegalensis occurs in riverine forests and is scattered within the higher-rainfall savannah woodlands. In moister areas, K. senegalensis is found on uplands, but it is restricted to riparian habitats or stream bottoms that extend into the savannah in the
The phytochemical sceening revealed the presence of limonoids (Caniato and Puricelli, 2003; Zhang et al., 2007), rearranged limonoid (Fall et al., 1999), limonoid $3 \alpha, 7 \alpha$-dideacetylkhivorin (Zhang et al., 2007), polyphenols from the bark (Androulakis et al., 2006)
- The bark is used as a vermifuge, taenicide, depurative and for treating syphilis. Bark extract is used for treating jaundice, dermatoses, scorpion bite, allergies, infection of the gums, hookworm, bleeding wounds (disinfectant), and as a laxative. Bark decoctions or macerations are widely taken against fever caused by malaria and against stomach complaints, diarrhoea, dysentery and anaemia, as anodyne in cases of rheumatism and headache, and as tonic, emmenagogue and anthelmintic. They are also used as purgative, antidote and abortifacient, and to treat syphilis, leprosy,
- The wood is valued for carpentry, joinery, furniture, cabinet work, ship building and decorative veneer. It is suitable for construction, flooring, interior trim, vehicle bodies, toys, novelties, railway sleepers, turnery and pulpwood. Traditionally, the wood is used for dug-out canoes, household implements such as mortars and

spoons, and drums. It is also used as fuelwood and for charcoal production. Wood ashes are used for conserving millet seed, as fish poison, as added to stored grain to prevent insect attack.

- The bark is used as an additive in local beer brewing and for dyeing cloth brownish. - The foliage is a common source of fodder, 
drier portions of the range. During the 1 st year, the seedling develops a strong, deep taproot, which makes it the most drought hardy of all the Khaya species. It is also very resistant to flooding and can be considered for planting on swampy soils. Moderately shade tolerant. Except where selectively removed by logging, dry-zone mahogany remains a dominant species in most of its range. Successful plantations of dryzone mahogany in other parts of the world have generally been in areas with short dry seasons and high rainfall.

\section{Biophysical limits}

Altitude: 0-1800 m, Mean annual temperature: $24.5-31.5 \mathrm{deg}$. C, Mean annual rainfall: 400-1750 mm Soil type: Tolerant to a wide range of soil conditions, from neutral to very strongly acidic and from very welldrained, coarse sandy loam to somewhat poorly drained clay. Prefers neutral, deep, sandy loam soil that is well drained. Such fertile conditions are often found in alluvial soils.

(Vogt, 1995; Sosef et al., 1998; Sokpon and Ouinsavi, 2004). chickenpox and angina. The bark is applied externally as disinfectant in cases of inflammations and to trea skin diseases, rash, scabies, wounds, ulcers, boils, haemorrhoids, swellings and toothache.

The bark is commonly used in veterinary medicine, as anthelmintic tonic and appetizer, and to trea trypanosomiasis, liver flukes, diarrhoea and ulcers. Bark also used in traditional veterinary practice, for example for cattle suffering from liver fluke, for ulcers in camels, donkeys and horses, and in horses for interna ailments associated with mucous diarrhoea.

- Seeds and leaves are used for treating fever, headache; roots against sterility, for the treatment of mental illness, against syphilis, leprosy and as an aphrodisiac. Crushed bark and seeds are regarded as emmenagogue. Seed oil is rubbed in to treat rheumatism and influenza, and it is taken to treat syphilis.

- Leaves are used in traditional medicine, to treat skin complaints, wounds, jaundice, oedema, headache and depression, and as purgative.

- Roots are applied against jaundice, stomach-ache oedema and amenorrhoea. The roots and/or bark are an ingredient of complex arrow poisons of which Strophanthus roots or seeds are the main ingredients.

- Flowers are used in medicines against stomach complaints and syphilis. but it has a low fodder quality. So, it is uesd in mixtures with better fodders.

- The seed oil is used in cosmetics and for cooking.

- Khaya senegalensis is commonly planted as a roadside tree and ornamental shade tree, and sometimes for soil stabilization. It has been planted successfully in a taungya system with groundnut as intercrop (FAO, 1986; Katende et al., 1995; Neuwinger, 1996 ; Sosef et al., 1998 ; Neuwinger, 2000 Arnold, 2004 ; Sokpon and Ouinsavi, 2004 ; Neya, 2006) 


\begin{tabular}{|c|c|c|c|}
\hline & & $\begin{array}{l}\text { (Katende et al., 1995; Neuwinger, } \\
1996 \text {; Sosef et al., 1998; Neuwinger, } \\
2000 ; \text { Potel, 2002; Caniato and } \\
\text { Puricelli, 2003; Arnold, 2004; } \\
\text { Sokpon and Ouinsavi, 2004; } \\
\text { Androulakis et al., 2006; Neya, 2006; } \\
\text { Lompo et al 2007; Zhang et al., 2007; } \\
\text { Pérez-Flores et al 2012). }\end{array}$ & \\
\hline \multicolumn{4}{|l|}{ 7. Lanea acida } \\
\hline $\begin{array}{l}\text { Lannea acida is a perennial tree } \\
\text { about } 8 \text { to } 12 \mathrm{~m} \text { height with scaly } \\
\text { bark, blackish-tranche red and yellow } \\
\text { striped fiber and is widely distributed } \\
\text { in the sudanian and guinean savanna } \\
\text { (Arbonnier, 2000; Mahamane et al., } \\
\text { 2007). }\end{array}$ & $\begin{array}{l}\text { Lannea acida has not been investigated for } \\
\text { its chemical composition. Only a } \\
\text { preliminary screening revealed the presence } \\
\text { of alkaloids and tannins in the bark (Etuk et } \\
\text { al., 2009). } \\
\text { Other studies, reported also a high levels of } \\
\text { phenolic compounds, and flavonoids in the } \\
\text { bark of L. acida (Karou et al., } 2005 \text {; } \\
\text { Ouattara et al., 2011). }\end{array}$ & $\begin{array}{l}\text { - Lannea acida bark, leaves, and roots, } \\
\text { are traditionnaly used combined or } \\
\text { sole for the treatment of conjunctivitis, } \\
\text { sores, diarrhoea, stomach aches, } \\
\text { gonorrhoea, rheumatism, fever, } \\
\text { malaria, skin deases, coughs, and } \\
\text { dysentery (Koné et al., } 2004 \text {; Ouattara } \\
\text { et al., 2011). } \\
\text { - The anti-bacterial and immune- } \\
\text { stimulating properties from the bark of } \\
\text { L. acida were scientifically proved and } \\
\text { reported (Koné et al., } 2004 \text {; Etuk et } \\
\text { al., 2009). } \\
\text { - The anti-mycobacterium of L. acida } \\
\text { bark was also successfull tested by } \\
\text { Ouattara et al., } 2011 \text {. } \\
\text { - In an other study of Ouattara et al., } \\
\text { 2011, Lannea acida bark demontrated } \\
\text { a high antioxydant activity. }\end{array}$ & $\begin{array}{l}\text { - The young leaves are eaten as vegetable. } \\
\text { - The bark was pounded to make red dye for } \\
\text { cloth. } \\
\text { - In some areas of West Africa a fermented } \\
\text { drink is made of the fruits. The fruit is also } \\
\text { used to resinous taste. } \\
\text { - The wood much used for making benches, } \\
\text { utensils and bows. It is also an excellent } \\
\text { combustible. } \\
\text { - Aerial parts, were browsed by livestock as } \\
\text { fodder. } \\
\text { (Burkill, 2000; Neuwinger, } 2000 \text {; Taïta, } \\
\text { 2000; Arbonnier, 2002). }\end{array}$ \\
\hline \multicolumn{4}{|l|}{ 8. Lanea microcarpa } \\
\hline $\begin{array}{l}\text { TLannea microcarpa Engl \& } \mathrm{K} . \\
\text { Krauss (Anacardiaceae) is a wild } \\
\text { fruit tree found in the Sudano- } \\
\text { Sahelian regions of Africa. The tree } \\
\text { grows up to } 16 \mathrm{~m} \text {. The bark is gray } \\
\text { white with a spiral twist; it is smooth } \\
\text { when the tree is young, becoming } \\
\text { splintery withage. The slash is red. }\end{array}$ & $\begin{array}{l}\text { Several studies have shown the presence of } \\
\text { anthocyanins and tannins in extracts of the } \\
\text { fruit epicarp of Lannea microcarpa, } \\
\text { fractionation and analysis of Lannea } \\
\text { microcarpa's polar extract allowed the } \\
\text { identification of 4'-methoxy-myricetin 3-O- } \\
\text { "-lrhamnopyranoside, myricetin 3-O-"-1- } \\
\text { rhamnopyranoside, myricetin 3-O-\$-d- }\end{array}$ & $\begin{array}{l}\text { - Lannea microcarpa leaves are used } \\
\text { for the treatment of diarrhoea, } \\
\text { gastroenteritis, malaria, bacterial } \\
\text { infections, toothaches, swellings, and } \\
\text { wound care (Nacoulma, 1996; } \\
\text { Arbonnier, 2002; Tapsoba and } \\
\text { Deschamps, 2006). } \\
\text { - The fruits are utilised to treat }\end{array}$ & $\begin{array}{l}\text { - Lannea microcarpa young leaves are eaten } \\
\text { as a vegetable and cattle browse it as a } \\
\text { forage. } \\
\text { - The bark is employed to dye cotton textiles } \\
\text { a red-brown colour. } \\
\text { - The fruits are eaten raw or dried and a } \\
\text { fermented drink is prepared from the pulp. } \\
\text { - Ropes are made from the very fibrous bark }\end{array}$ \\
\hline
\end{tabular}


The leaves are comprised of 1-3 pairs of asymmetrical leaflets, plus the terminal one. The leaflets are ovate-lanceolate, obtuse and unequal at the base; they are $5.5-13 \mathrm{~cm}$ long and $2.7-4.5 \mathrm{~cm}$ wide. The new growth has short, close and simple hairs. The flowers are small, green yellowish with glabrous sepals. The flowers crowd at the end of the branches.

Lannea microcarpa occurs in savanna vegetation. It prefers deep friable soil and is often found on cultivated land, where it is not cut down but preserved for its edible fruits. It also occurs on rocky soil in Sahel savanna (Burkill, 2000; Arbonnier, 2004 ; Ajiboye et al., 2013).

\section{Momordica charantia}

M. charantia, a climber belonging to family Cucurbitaceae, is commonly known as bitter gourd or bitter melon in English. Momordica means, "to bite"-referring to the jagged edges of the leaf, which appear as if bitten. All parts of the plant, including the fruit, taste bitter. It is a monoecious annual climbing or trailing herb with stems up to $5 \mathrm{~m}$ long. The fruit is oblong and resembles a small cucumber, young fruit is emerald green that turns to orange yellow when ripe.

The plant grows in tropical areas of Asia, Amazon, Africa, and the Caribbean glucopyranoside, vitexin, isovitexin, gallic acid and epi-catechin (Picerno et al., 2006 ; Bationo et al., 2012).

The presence of cyanidin 3-0-(2-0- $\beta$-Dxylopyranosyl) $\beta$-D-galactopyranoside and cyanidin 3-0- $\beta$-D-galactopyranoside was also reporteed in the dry fruit epicarp (Ouattara et al., 2011; Ajiboye et al., 2013).

Tannins (deriving from gallic acid) are present in the bark (Duponchel, 2004) scurvy, rickets and cough.

- The bark and roots are used to treat stomach pain, rheumatism, gonorrhea, diarrhoea, rachitism, chest pain, gastric ulcer, wounds, skin and respiratiry tract deases.

They are also applied to treat mouth blisters, sore throat, dysentery, as a cathartic and as a dressing on boils (Burkill, 2000 ; Kamanzi et al., 2004 ; Koné et al., 2004).

- The bark is used as antibacterial and anti-hypertensive (Lamien-Meda et al. 2008; Ouattara et al., 2011; Ouedraogo et al., 2010 ; Bationo et al. 2012).

- Wood ash is applied to maturate abscesses. of Lannea microcarpa.

(Palé et al., 1998 ; Burkill, 2000 ; Tapsoba and Deschamps, 2006 ; Bationo et al., 2012 ; Ajiboye et al., 2013)
M. charantia contains biologically active chemicals that include glycosides, saponins, alkaloids, fixed oils, triterpenes, proteins and steroids (Raman and Lau, 1996)

Several phytochemicals such as momorcharins, momordenol, momordicilin, momordicins, momordicinin, momordin, momordolol, charantin, charine, cryptoxanthin, cucurbitins, cucurbitacins, cucurbitanes, cycloartenols, diosgenin, elaeostearic acids, erythrodiol, galacturonic acids, gentisic acid, goyaglycosides, goyasaponins, multiflorenol, have been isolated (Husain et al., 1994; Xie et al., 1998;

Yuan et al., 1999; Parkash et al., 2002).
Antidiabetic (fruit pulp, seed, leaves and whole plant) (Ahmed et al., 1998; Sitasawad et al., 2000; Ahmed et al., 2001; Miura et al., 2001; Grover et al., 2002; Rathi et al., 2002a,b).

- Antibacterial (leaves, fruit extract, whole plant) (Khan et al., 1998 ; (Omoregbe et al., 1996; Khan et al. 1998 ; Yesilada et al., 1999 ; Frame et al., 1998).

- Anti - HIV (whole plant) (Zheng et al., 1999; Au et al., 2000 ; Wang and $\mathrm{Ng}$, 2001a; Jiratchariyakul et al., 2001)

- Anti-cancer (whole plant) (Battelli et al. 1996; Kusamran et al., 1998 ; Ganguly et al., 2000; Sun et al., 2001;
- The seeds, leaves, fruits, vines, are used as foods

- Tender fruits of the plant are eaten as vegetable in stew or are pickled; they are use also for flavoring food dishes.

- The leaves and fruit are both been used occasionally to make teas and beer, or to season soups.

- The leaves and stem are used as camel fodder (Assubai and El-Garawany, 2004 ; Grover and Yadav, 2004; Ahmad et al., 2012 ;).

- The brigh red seeds of some fruits of $\mathrm{M}$ charantia are used as natural colorant. 


\begin{tabular}{|c|c|c|c|}
\hline $\begin{array}{l}\text { The plant is adapted to a wide } \\
\text { variations of climates although } \\
\text { production is best in hot areas } \\
\text { (Grover and Yadav, 2004). }\end{array}$ & $\begin{array}{l}\text { These are reported in all parts of the plant } \\
\text { (Murakami et al., 2001). } \\
\text { HIV inhibitory proteins like MRK29 (MW: } \\
28.6 \mathrm{kDa} \text { ), MAP30 (MW: 30,000 kDa) and } \\
\text { lectin are documented } \\
\text { (Putnam and Tainer, 2000; Jiratchariyakul } \\
\text { et al., 2001; Wang and Ng, 2001a). } \\
\text { The presence of trypsin inhibitors (Hamato } \\
\text { et al., 1995; Chakraborty et al., 2000), } \\
\text { elastase inhibitors (Hamato et al., 1995), } \\
\text { guanylate cyclase inhibitors (Takemoto et } \\
\text { al., 1980) and alpha-glucosidase inhibitor } \\
\text { like D-(+)-trehalose are reported (Matsuur } \\
\text { et al., 2002). }\end{array}$ & $\begin{array}{l}\text { Basch et al., 2003;). } \\
\text { - Abortifacient and antifertility (whole } \\
\text { plant) (Naseem et al., } 1998 \text {; Schreiber } \\
\text { et al., 1999; Matsuda et al., 1999; } \\
\text { Yesilada et al., 1999; Gurbuz et al., } \\
\text { 2000). } \\
\text { - Anti-anthelmintic (whole plant) (Lal } \\
\text { et al., 1976). } \\
\text {-Anti-malarial (whole plant) (Munoz et } \\
\text { al.; 2000; Kohler et al., 2002). } \\
\text { - Analgesic and antinflammatory } \\
\text { activity (whole plant) (Biswas et al., } \\
\text { 1991; Choi et al., 2002). }\end{array}$ & \\
\hline \multicolumn{4}{|l|}{ 10. Pterocarpus erinaceus } \\
\hline $\begin{array}{l}\text { Pterocarpus erinaceus } \begin{array}{r}\text { Poir. } \\
\text { subfamily }\end{array} \\
\text { Papilionoideae) is a small to } \\
\text { medium-sized tree } 12-15 \mathrm{~m} \text { tall with } \\
\text { a diameter of } 1.2-1.8 \mathrm{~m} \text {. In the drier } \\
\text { part of its range it has an open, } \\
\text { spreading form and is low-branching, } \\
\text { but under favorable rainfall and soil } \\
\text { conditions, much larger specimens } \\
\text { with clean straight boles } 6-8 \mathrm{~m} \text { long } \\
\text { or more can be found. Exceptionally } \\
\text { tall trees reaching } 35 \mathrm{~m} \text { height have } \\
\text { been reported (von Maydell 1983; } \\
\text { ICRAF 1998, Touré, } 2001 \text {; } \\
\text { Arbonnier, 2004). } \\
\text { Pterocarpus erinaceus is found } \\
\text { throughout West and Central Africa, } \\
\text { ranging from Senegal in the west to } \\
\text { the Central African Republic in the } \\
\text { east. It is distributed up to } 14^{\circ} \mathrm{N} \text { but } \\
\text { is a stunted, small tree at this latitude. } \\
\text { Southward, the range extends to the } \\
\text { limit of the humid forest in Cote }\end{array}$ & $\begin{array}{l}\text { The pytochemical screening of stem bark } \\
\text { revealed the presence of tannins, flavonoids } \\
\text { such as epicatechin, phenolic compounds, } \\
\text { and triterpenoids such as friedelin and } \\
\text { lupeol (Ouédraogo et al., 2012). } \\
\text { Note that the reddish bark exudate contains } \\
30-80 \% \text { kinotannic acid (Ouedraogo-Koné } \\
\text { et al., 2008). }\end{array}$ & $\begin{array}{l}\text { - The reddish bark exudate (kino) is } \\
\text { commonly used in traditional } \\
\text { medicine, internally to treat diarrhoea, } \\
\text { dysentery, fever, gonorrhoea and } \\
\text { intestinal worm infections, and } \\
\text { externally to treat eye complaints, } \\
\text { ulcers and sores. Kino was also used } \\
\text { against chronic diarrhoea (Burkill, } \\
1995 \text {; Abreu et al., } 1999 \text {; Potel, } \\
2002 \text {; Karou et al., 2005; Koné et al., } \\
\text { 2006). } \\
\text { - Decoctions or infusions of bark or } \\
\text { roots serve for treating bronchial } \\
\text { infections, toothache, dysentery, } \\
\text { menstruation complaints, anaemia, } \\
\text { gonorrhoea, post-partum haemorrhage, } \\
\text { ringworm infections, leprosy, wounds, } \\
\text { tumours and ulcers, and as an anti- } \\
\text { emetic, purgative and tonic (Abreu et } \\
\text { al., 1999; Neuwinger, 2000; Diallo et } \\
\text { al., 2002; Karou et al., 2005; } \\
\text { Nadembega et al., 2011). } \\
\text { - The bark is also used against tooth }\end{array}$ & $\begin{array}{l}\text { - The reddish bark exudate (kino) is beaten } \\
\text { onto cloth with a mallet to give it a glaze. } \\
\text { The kino, is used for dyeing cloth to produce } \\
\text { a dark purple color. The bark is occasionally } \\
\text { used for tanning (Burkill, 1995). } \\
\text { - The wood is used for heavy construction } \\
\text { including waterworks, parquet flooring, } \\
\text { stairs, implements, turning, sculpturing and } \\
\text { sliced veneer. It is also suitable for joinery, } \\
\text { interior trim, mortars, pestles, house posts, } \\
\text { mine props, ship and boat building, vehicle } \\
\text { bodies, sporting goods, toys, novelties, } \\
\text { musical instruments (e.g. balafons) and } \\
\text { precision equipment. The wood is also } \\
\text { suitable for fuel and charcoal production. The } \\
\text { heartwood is a source of a red dye, which is } \\
\text { used for dying cloth, the body or hair (von } \\
\text { Maydell 1983; Roussel, 1995; Roussel, } \\
\text { 1996; Toure, 2001; CAB, 2005). } \\
\text { - Leaves decoction is used as an aphrodisiac } \\
\text { and insect repellent (Burkill, 1995). } \\
\text { - Leafy branches are browsed by livestock, } \\
\text { and are especially important towards the end }\end{array}$ \\
\hline
\end{tabular}




\begin{tabular}{|c|c|c|c|}
\hline 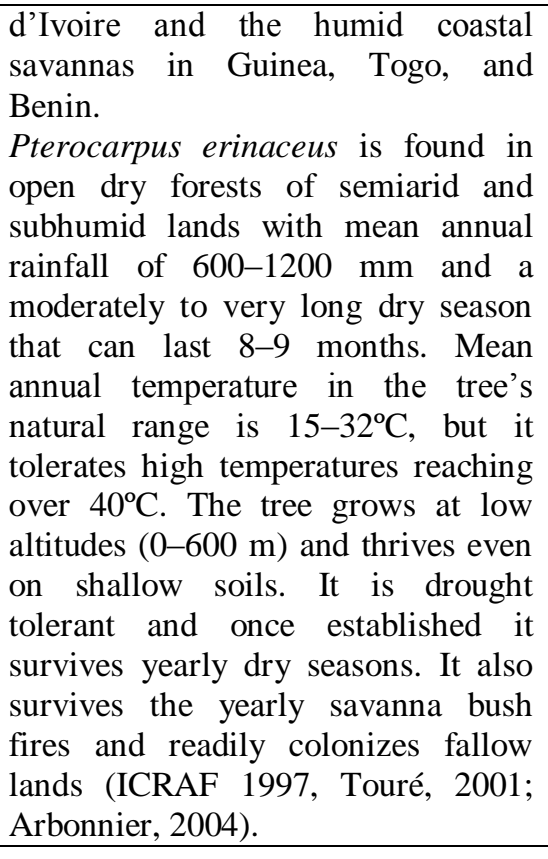 & & $\begin{array}{l}\text { and mouth troubles (von Maydell } \\
\text { 1983). } \\
\text { - Roots preparations are administered } \\
\text { as an enema to treat venereal diseases. } \\
\text { The grated root is mixed with tobacco } \\
\text { and smoked in a pipe as a cough } \\
\text { remedy (von Maydell 1983; Touré, } \\
\text { 2001). } \\
\text { - Leaves decoctions are applied to treat } \\
\text { fever, syphilis, and as febrifuge } \\
\text { (Burkill, 1995; Potel, 2002). }\end{array}$ & $\begin{array}{l}\text { of the dry season when not much else is } \\
\text { available (Roussel, 1996; Akaplu, 1998; } \\
\text { Bonkoungou et al. 1998; Touré, 2001; } \\
\text { Ouedraogo-Koné et al., 2008). }\end{array}$ \\
\hline & & & \\
\hline $\begin{array}{l}\text { Tamarindus is amonospecific genus } \\
\text { that was formerly placed in the } \\
\text { Caesalpiniaceae family, now drawn } \\
\text { up in Fabaceae sensu lato. } \\
\text { Tamarindus indica is a pantropical } \\
\text { species and is commonly used all } \\
\text { over the world (Morton, 1987). For } \\
\text { fruit development a dry season is } \\
\text { required. Its African range runs along } \\
\text { the dryland zone from Senegal in the } \\
\text { west through Sudan and Ethiopia in } \\
\text { the east, extending southward to } \\
\text { Mozambique and Madagascar } \\
\text { (World Agroforestry Centre, 2007). } \\
\text { In West Africa, it is characteristic of } \\
\text { the dry Sahel and northern Soudan2 }\end{array}$ & $\begin{array}{l}\text { Differences in values found in the literature } \\
\text { are likely to be due to differences in genetic } \\
\text { strains, stages of maturity at which the } \\
\text { plant parts were } \\
\text { harvested, growing conditions (Glew et al., } \\
\text { 2005), harvesting and handling techniques } \\
\text { as well as to differences in analytical } \\
\text { methodologies (De Caluwé et al., 2009). } \\
\text { Tamarind pulp typically contains } 20.6 \% \\
\text { water, 3.1\% protein, 0.4\% fat, } 70.8 \% \\
\text { carbohydrates, 3.0\% fibre and } 2.1 \% \text { ash (El- } \\
\text { Siddig et al., 1999), thus the pulp has a low } \\
\text { water content and a high level of protein, } \\
\text { carbohydrates and minerals. The fruit pulp } \\
\text { contains very little linoleic acid (3.42 mg/g } \\
\text { dry weight) and even lower amounts of } \alpha-\end{array}$ & $\begin{array}{l}\text { Medicinal uses of tamarind are } \\
\text { uncountable (Morton, 1987). We } \\
\text { expose here someone of theses. } \\
\text { - Fortifiant (fruit pulp, bark and leaves) } \\
\text { ( Doughari, 2006). } \\
\text { - Treatement of jaundice (bark and } \\
\text { leaves) (Doughari, 2006). } \\
\text { - Treatment of heart deases (fruit) } \\
\text { (Fandohan, 2007). } \\
\text { - Treament of hypertension (leaves) } \\
\text { (Norscia and Borgognini-Tarli, 2006). } \\
\text { - Against abdomian pain (bark, fruit, } \\
\text { leaves, roots) (Geissler et al., 2002; } \\
\text { Kristensen and Balslev, 2003; } \\
\text { Doughari, 2006; Norscia and } \\
\text { Borgognini-Tarli, 2006; Fandohan, }\end{array}$ & $\begin{array}{l}\text { - Tamarind fruit pulp is used for seasoning, } \\
\text { as a food component, to flavour confections, } \\
\text { curries and sauces, and is a main component } \\
\text { in juices and certain beverages. Tamarind } \\
\text { fruit pulp is eaten fresh and often made into a } \\
\text { juice, infusion or brine (El-Siddig et al., } \\
\text { 1999; El-Siddig et al., 2006) } \\
\text { - Sometimes pulp is fermented into an } \\
\text { alcoholic beverage (FAO (1988) cited in El- } \\
\text { Siddig et al., 2006). } \\
\text { - The bark is rich in tannins reaching up to } \\
70 \% \text {, and as such has found a place for use in } \\
\text { the tanning industry. The bark is used for } \\
\text { tanning hides and in dyeing (Morton, 1987; } \\
\text { El-Siddig et al., 2006). } \\
\text { - The seeds is also use in industry. The major }\end{array}$ \\
\hline
\end{tabular}




\begin{tabular}{|c|c|c|c|}
\hline $\begin{array}{l}\text { climatic zones, but becomes less } \\
\text { common toward the more humid } \\
\text { Guinea savanna (Havinga et al., } \\
\text { 2010). }\end{array}$ & $\begin{array}{l}\text { linolenic acid (0.21 mg/g dry weight); it is } \\
\text { also have high content of vitaminB, } \\
\text { vitaminC, maganese, zinc, calcium and } \\
\text { phosphorus (El-Siddig et al., 1999; Glew } \\
\text { et al., 2005). } \\
\text { The seeds have high content of protein, } \\
\text { mineral especially magnesium and } \\
\text { potatium, and many fatty acid such as } \\
\text { linoleic acid (Ajayi et al., 2006). The seeds } \\
\text { also contain small amounts of anti- } \\
\text { nutritional factors such as tannins, phytic } \\
\text { acid, hydrogen cyanide, trypsin inhibitor } \\
\text { activity and phytohaemaglutination activity } \\
\text { (El-Siddig et al., 2006). } \\
\text { The leaves and roots of tamarind contain a } \\
\text { number of glycosides such as vitexin, } \\
\text { isovitexin, orientin and isoorientin (Morton, } \\
\text { 1987). } \\
\text { The bark is rich in tannins reaching up to } \\
\text { 70\% (Morton, 1987; El-Siddig et al., 2006). }\end{array}$ & $\begin{array}{l}\text { 2007). } \\
\text { - Treatment of diabete (leaves) (Maitin } \\
\text { et al., } 2004 \text { cited in El-Siddig et al., } \\
\text { 2006; Baldé et al., 2006) } \\
\text { - Contraceptive (roots) (Ahua et al., } \\
\text { 2007). } \\
\text { - Treatment of infertility (all arial } \\
\text { parts) (Alawa et al., 2002). } \\
\text { - Against cold (fruit pulp) (Fandohan, } \\
\text { 2007). } \\
\text { - Against malaria (bark, leaves, fruits) } \\
\text { (Asase et al., 2005; Makundi et al., } \\
\text { 2006; Fandohan, 2007; Tabuti, 2008). } \\
\text { - Against parasitic worms ( bark, fruit, } \\
\text { leaves, roots, seeds) (Hewlett and } \\
\text { Cline, 2001; Inngjerdingen et al., } \\
\text { 2004; Bah et al., 2006; ). } \\
\text { - Against microbial infections (fruit) } \\
\text { (Magassouba et al., 2007) } \\
\text { - Against blackged (roots, bark) (Abdu } \\
\text { et al., 2000; Useh et al., 2006). } \\
\text { - Treament of sleeping sickness } \\
\text { (leaves, fruit) (Atawodi et al., 2002). } \\
\text { - Syphilis (roots) (Tabuti et al., 2003). } \\
\text { - Yellow fever (bark and leaves) } \\
\text { (Doughari, 2006). } \\
\text { - Treatment of epilepsy (roots) (Moshi } \\
\text { et al., 2005). } \\
\text { - Lactation (fruit) (Lockett and } \\
\text { Grivetti, 2000). }\end{array}$ & $\begin{array}{l}\text { industrial product of tamarind seed is the } \\
\text { tamarind kernel powder (TKP) which is an } \\
\text { important sizing material used in the textile, } \\
\text { paper, and jute industries (Kumar \& } \\
\text { Bhattacharya, 2008). } \\
\text { - Tamarind leaves and flowers are eaten as } \\
\text { vegetables and are prepared in a variety of } \\
\text { dishes (ICRAF, 2007). They are used to } \\
\text { make curries, salads, stews and soups in } \\
\text { many countries, especially in times of } \\
\text { scarcity. } \\
\text { Before consumption, leaves are sometimes } \\
\text { boiled in water and prepared as tamarind } \\
\text { fruits (Nordeide et al., 1996). }\end{array}$ \\
\hline
\end{tabular}




\section{CONCLUSION}

The monographic study of these plants most commonly used for the treatment of common ailments Somba cattle has been successful in the premise of these plants as medicinal plants. Indeed, in many work already done, the medicinal uses of each of these plants are reported in many works by several authors around the world, particularly in Africa, Asia, and Latin America. Any time these uses are found mostly in human medicine. Uses in veterinary medicine are still significantly lower.

Phytochemical screening of extracts or parts of these plants made in various studies have put in evidence compounds such as tannins, flavonïdes, triterpenes,

\section{REFERENCES}

1. Adanléhoussi A, Bassowa $\mathrm{H}$, Défly A, Djabakou K, Adoméfa K, Kouagou NT. 2003. Les performances de la race taurine Somba en milieu paysan. Tropicultura, 21(3): 135-141

2. Dossa SC. 2000. Preliminary studies on the importance of ticks and tick-borne diseases inpurebred Somba in Benin. Project INCO-SOMBA, Report, p. 89

3. PAMRAD, Benin. 2006. Recensement et diagnostic de l'élevage de la race Somba dans la Commune de Boukombé. Rapport provisoire, p. 62

4. Sokouri DP, Yapi-Gnaore CV, N'guetta ASP, Loukou NE, Kouao BJ, Toure G, Kouassi Sangare A. 2010. Breeding performances of the local cattle breeds in Côte d'Ivoire. $J$. Appl. Biosci., 36: 2353- 2359.

5. Chabi China TF, Adénilé A, Doko Allou S, Olounlade PA, Hounzangbe-Adote MSG, Abiola FA, Salifou S, 2013. Zootechnical study of breeding modes of somba cattle in Benin, Int. J. Biol. Chem. Sci, 7(6), 2193-2201.

6. Chabi China TF, Olounladé PA, Salifou S, 2014. Ethnobotanical study of endogenous methods used for the treatment of diseases of Somba cattle breed in northen Benin. Journal of drug delivery and therapeutics, 4 (3):

7. Wickens, G.E. (1982). The Baobab-Africa's upside-down tree. Kew Bulletin, 37, 173-209.

8. Chadare, F.J., Linnemann, A.R., Hounhouigan, J.D., Nout, M.J.R., Van Boekel, M.A.J.S. (2009). Baobab Food Products: A Review on their Composition and Nutritional Value. Critical Reviews in Food Science and Nutrition, 49, 254-274.

9. Drake, E., 2006. A Book of Baobabs. Aardvark Press, Cape Town.

10. Wickens, G.E., Lowe, P., 2008. The baobabs: pachycauls of Africa. Madagascar Australia, Springer, UK.

11. Gebauer, J., El-Siddig, K., Ebert, G. (2002). Baobab (Adansonia digitata L.): a Review on a Multipurpose Tree with Promising Future in the Sudan. Gartenbauwissenschaft, 67, 155-160.

12. Venter, F., Venter, J.-A., 1996. Making the Most of Indigenous Trees. Briza Publications, Pretoria.

13. Chauhan, J.S., Kumar, S., Cahturvedi, R., 1987. Anew flavonone glycoside from the root of A. digitata. National Academy of Science Letters 10, 177-179.

14. Shukla YN, Dubey S, Jain SP, Kumar S. Chemistry, biology and uses of Adansonia digitata. A reiew. J Medi Arom Plant Sci. 2001; 23: 429-34

15. Cisse, M., Sakho, M., Dornier, M., Diop, C.M., Reynes, M., Sock, O. (2009). Caractérisation du fruit du baobab et étude de sa transformation en nectar, Fruits, 64, 19-34.

16. Shahat, A.A., 2006. Procyanidins fromA dansonia digitata. Pharmaceutical Biology 44, 445-450. alkaloids, steroids, etc. anthracene derivatives. All these compounds are known to have pharmacological properties and their abundant presence or not in the plants tested confirm the therapeutic potential of these plants.

Note however that there is very little literature on the experimental works of these plants on the diseases supposed treated. Thus, among the many pharmacological and therapeutic properties of these plants reported by different peoples from around the world, very few have been studied and scientifically proven in both human and veterinary medicine. It therefore remains a whole area to explore, and our future studies will explore this.

17. Bianchini, J.-P., Ralaimanarivo, A., Gaydou, E.M., Waegell, B., 1982. Hydrocarbons, sterols and tocopherols in the seeds of six Adansonia species. Phytochemistry 21, 1981-1987.

18. Glew, R.H., VanderJagt, D.J., Lockett, C., Grivetti, L.E., Smith, G.C., Pastuszyn, A., Millson, M. (1997). Amino Acid, Fatty Acid and Mineral Composition of 24 Indigenous Plants of Burkina Faso. Journal of Food Composition and Analysis, 10, 205-217.

19. Sibibe, M., Williams, J.T. (2002). Baobab - Adansonia digitata. Fruits for the future 4, International Centre for Underutilised Crops, Southampton, UK, 96p.

20. Van Wyk, B.-E., Gericke, N., 2000. People's plants-A guide to useful plants of Southern Africa. Briza Publications, Pretoria.

21. Brendler, T., Gruenwald, J., Jaenicke, C., 2003. Herbal Remedies. Medpharm GmbH Scientific Publishers (CDROM), Stuttgart.

22. Tapsoba, H. and J.P. Deschamps, 2006. Use of medicinal plants for the treatment of oral diseases in BurkinaFaso. J. Ethnopharmacol., 104: 68-78.

23. De Caluwé, E., Halamová, K., Van Damme, P., 2009. Baobab (Adansonia digitata L.): a review of traditional uses, phytochemistry and pharmacology. In: Rodolfo, H., Simon, J.E., Ho, C.-T. (Eds.), African natural plant products: new discoveries and challenges in chemistry and quality. Oxford University Press, USA, pp. 51-84.

24. Nguta, J.M., Mbaria, J.M., Gakuya, D.W., Gathumbi, P.K., Kiama, S.G.,2010. Antimalarial herbal remedies of Msambweni, Kenya. Journal of Ethnopharmacology 128, 424-432.

25. Denloye, A.A.B., Teslim, K.O., Fasasi, O.A., 2006. Insecticidal and repellency effects of smoke from plant pellets with or without D-allethrin $90 \mathrm{EC}$ against three medical insects. Journal of Entomology 3, 9-15.

26. Royal Botanic Gardens, Kew, 1999. Survey of economic plants for arid and semi arid lands (SEPASAL) database. Available at: http://www.rbgkew. org.uk/ceb/sepasal1999 [Accessed on: 10/04/2011].

27. Nhukarume, L., Chikwambi, Z., Muchuweti, M., Chipurura, B., 2008. Phenolic content and antioxidant capacities of Parinari curatelifolia, Strychnos spinosa and Adansonia digitata. Journal of Food Biochemistry 34, 207-221

28. Yusha'u, M., Hamza, M.M., Abdullahi, N., 2010. Antibacterial activity of Adansonia digitata stem bark extracts on some clinical bacterial isolates. International Journal of Biomedical and Health Sciences 6, 129-135.

29. Wren, S., Stucki, A., 2003. Organic essential oils, indigenous cold pressed oils, herbs and spices in Sub- 
Saharan Africa. International Journal of Aromatherapy 23, 71-81.

30. Oteng-Amoako, A.A. (Editor), 2006. 100 tropical African timber trees from Ghana: tree description and wood identification with notes on distribution, ecology, silviculture, ethnobotany and wood uses. 304 pp.

31. Hawthorne, W. \& Jongkind, C., 2006. Woody plants of western African forests: a guide to the forest trees, shrubs and lianes from Senegal to Ghana. Kew Publishing, Royal Botanic Gardens, Kew, United Kingdom. 1023 pp

32. Neuwinger, H.D., 2000. African traditional medicine: a dictionary of plant use and applications. Medpharm Scientific, Stuttgart, Germany. 589 pp.

33. Arbonnier, M., 2004. Trees, shrubs and lianas of West African dry zones. CIRAD, Margraf Publishers Gmbh, MNHN, Paris, France. 573 pp

34. Orwa, C., Mutua, A., Kindt, R., Jamnadass, R. \& Simons, A., 2009. Agroforestree database: a tree reference and selection guide. Version 4.0. [Internet] World Agroforestry Centre (ICRAF), Nairobi, Kenya.

35. Ejikeme PM, Obasi LN and Egbuonu ACC, 2010. Physico-chemical and toxicological studies on Afzelia africana seed and oil. African Journal of Biotechnology Vol. 9 (13), pp. 1959-1963

36. Bationo, B.A., Ouedraogo, S.J. \& Guinko, S., 2001. Longévité des graines et contraintes à la survie des plantules d'AFZELIA africana $\mathrm{Sm}$. dans une savane boisée du Burkina Faso. Annals of Forest Science 58(1): 69-75.

37. Koch, G., Richter, H.G. \& Schmitt, U., 2006. Topochemical investigation on phenolic deposits in the vessels of AFZELIA (AFZELIA spp.) and merbau (Intsia spp.) heartwood. Holzforschung 60: 583-588.

38. Sakande, M., 2007. Afzelia africana. Seed leaflet No 118. Millenium Seed Bank Project. Forest \& Landcape Denmark. 2 pp.

39. Ikhimioya I and Imasuen JA, 2007. Blood profile of west African Dwarf Goats fed Panicum maxium supplemented with Afzelia Africana and Newbouldia laevis. Pakistan Journal of Nutrition 6 (1): 79-84

40. Atawodi SE, D.A. Ameh, S. Ibrahim, J.N. Andrew, H.C. Nzelibe, E.O. Onyike, K.M. Anigo, E.A. Abu, D.B. James, G.C. Njoku, A.B. Sallau, 2002. Indigenous knowledge system for treatment of trypanosomiasis in Kaduna state of Nigeria. Journal of Ethnopharmacology 79 (2002) 279-282 Short communication.

41. Nkafamiya, I.I., Osemeahon, S.A., Dahiru, D., Umaru, H.A., 2007. Studies on the chemical composition and physicochemical properties of the seeds of baobab (Adasonia digitata). African Journal of Biotechnology 6, 756-759.

42. Magassouba FB, A. Diallo, M. Kouyaté, F. Mar, O. Maraa, O. Bangoura , A. Camara, S. Traoré, A.K. Diallo , M. Zaoro, K. Lamah, S. Diallo , G. Camara, S. Traoré, A. Kéita, M.K. Camara, R. Barry, S. Kéita, K. Oularé, M.S. Barry, M. Donzo, K. Camara, K. Toté, D. Vanden Berghe, J. Totté, L. Pieters, A.J. Vlietinck, A.M. Baldé, 2007. Ethnobotanical survey and antibacterial activity of some plants used in Guinean traditional medicine. Journal of Ethnopharmacology 114: 44-53

43. Burkill, H.M., 1995. The useful plants of West Tropical Africa. 2nd Edition. Volume 3, Families J-L. Royal Botanic Gardens, Kew, Richmond, United Kingdom. 857 pp.

44. Aye and Adeyey, 2002. Feed intake and weight changes of West African Dwarf goats fed different levels of Afzelia africana pods. In: Proceedings of the 27th Annual Conference of the Nigerian Society of Animal Production, 17-21 March 2002, Federal University of Technology, Akure, Nigeria. Pp 212-213.
45. Normand, D. \& Paquis, J., 1976. Manuel d'identification des bois commerciaux. Tome 2. Afrique guinéocongolaise. Centre Technique Forestier Tropical, Nogentsur-Marne, France. 335 pp.

46. Louppe, D., 2000. AFZELIA africana: une essence précieuse et plastique. Poster abstract. In: UFRO. Forests and Society: the role of research. Vienna, Austria.

47. Kolawole OM, Oguntoye SO, Agbede O and Olayemi AB. 2007. Studies on the efficacy of bridelia ferruginea benth bark extract for domestic wastewater treatment Bull. Chem. Soc. Ethiop., 21(2), 205-211. ISSN 1011-3924

48. Lagnika L, Murielle HT, Fantodji and Ambaliou Sanni A. 2012. Phytochemical study and antibacterial, antifungal and antioxidant properties of bridelia ferruginea and pteleopsis suberosa. IJPSR, 2012; Vol. 3(7): 2130-2136

49. Cimanga, K., De-Bruyne, T., Apers, S., Pieters, L., Totte, M.J., Kambu, K., Tona, L., Bakana, P., van Ufford, L.Q., Beukelman, C., Labadie, R., Vlietinck, A.J., 2001. Complement-inhibiting constituents of Bridelia

ferruginea stem bark. Planta Medica 65, 213-217

50. De-Bruyne, T., Cimanga, K., Pieters, L., Claeys, M., Dommisse, R.,Vlientick, A.J., 1998. Gallocatechin-(4-07) epigallocatechin, a new biflavonoid isolated from Bridelia ferruginea. Natural Products Letters

$11,47-52$

51. Adjanohoun EJ, Adjakidjè V, Ahyi MRA, Akeassi L, Akoegninou A, d'Almeida $J$, et al: Médecine traditionnelle et pharmacopée. Contribution aux études ethnobotaniques et floristiques en République du Bénin. Paris, Agence de Coopération Culturelle et Technique, pp. 339. 1989.

52. Fujii, E., Yoshioka, T., Ishida, H., Irie, K., Muraki, T., 2000. Evaluation of iNOS dependent and independent mechanisms of the microvascular permeability change induced by lipopolysaccharide. British Journal of Pharmacology 130, 90-94.

52. Wada, K., Fujii, E., Ishida, H., Yoshioka, T., Muraki, T., 2000. Effect of lipoteichoic acid on dermal vascular permeability in mice. Journal of Pharmacology and Experimental Therapeutics 294, 280-286.

53. Olajide, O.A., Makinde, J.M., Okpako, D.T., Awe, S.O., 2000. Studies on the anti-inflammatory and related pharmacological properties of the aqueous extract of Bridelia ferruginea stem bark. Journal of

Ethnopharmacology 71, 153-160..

54. Olumayokun A, Olajide, David T, Okpako, Janet $M$, Makinde, 2003. Anti-inflammatory properties of Bridelia ferruginea stem bark Inhibition of lipopolysaccarideinduced septic shock and vascular permeability. Journal of Ethnopharmacology 88 (2003) 221-224

55. Adetutu, A., Morgan W.A., Corcoran O. 2011. Ethnopharmacological survey and in vitro evaluation of wound-healing plants used in Southwestern Nigeria. Journal of Ethnopharmacology; 137 (1): 50- 56.

56. Fabiyi, M.; Goel, R.; Snowling, S.; Novak, R. , 2012. Reduction of VOC Emissions in High Purity Oxygen Activated Sludge Wastewater Treatment Process: Toxchem Based Fate \& Emissions Modeling Case Study. AIChE Annual Meeting, Conference Proceedings; Pittsburgh, PA, Oct 2 - Nov 2: American Institute of Chem. Engineers.

57. Zunjar V., Mohamed D., Trivedi B.M., Daniel M., 2011. Pharmacognostic, phytochemical studies on Carica papaya Linn. leaves. Pharmacognosy Journal, (3): 5-8

58. Milind $P$ and Gurditta, 2012. Basketful benefits of papaya.Int res J Pharm, 7: 6-12

59. Krishna, K.L., Paridhavi ,M., Patel, A.J., 2008. Review on nutritional, medicinal and pharmacological properties of papaya (Carica papaya Linn). Natural Product Radiance 7,364-373. 
60. Gurung, S., Skalko, N.B., 2009. Wound healing properties of C. papaya latex: in vivo evaluation in mice burn model. Journal of Ethnopharmacology121,338-341.

64. Kabebew and Shibeshi, 2013. Evaluation of anxiolytic and sedative effects of $80 \%$ ethanolic Carica papaya L. (Caricaceae) pulp extract in mice. Journal of Ethnopharmacology 150 (2013) 665-671

61. Varisha A, Husain AS, Javed NK, Poonam A, 2013. Physico-chemical and phytochemical evaluation of Carica Papaya LINN unripe fruits. Int. Res. J. Pharm. 4 (8) : 101106.

62. Marelli de Souza, L., Silva Ferreira, K., Paes Chaves, J. B., \& Lopes Teixeira, S. (2008). LAscorbic acid, $\beta$-Caroteno and lycopene content in papaya fruits (Carica papaya) without physiological skin freckles. Science Agriculture, 65(3), 246-250.

63. Andersson, S. C., Olsson, M. E., Johansson, E., \& Rumpunen, K. (2009). Carotenoids in sea buckthorn (Hippophae rhamnoides L.) berries during ripening and use of pheophytin a as a maturity marker. Journal Agricultural of Food Chemistry, 57,250-258.

64. Rivera-Pastrana, D. M., Yahia, E. M., \& Gonzalez-Aguilar, G. (2010). Phenolic and carotenoid profiles of papaya fruit (Carica papaya L.) and their contents under low temperature storage. Journal of the Science of Food and Agriculture, 90, 2358-2365.

65. Yahia, M. E., \& Ornelas-Paz, J. J. (2010). Chemistry, stability and biological actions of carotenoids. In L. A. de la Rosa, E. Alvarez-Parrilla, \& G. A. Gonzalez-Aguilar (Eds.), Fruit and vegetable phytochemicals (pp. 177-222). USA: Wiley-Blackwell.

66. Gayosso-García Sancho, L. E., Yahia, E. M.,MartínezTéllez,M. A., \& González-Aguilar, G. A. (2010). Effect of maturity stage of papaya Maradol on physiological and biochemical parameters. American Journal of Agricultural and Biological Sciences, 5(2), 199-208.

67. Nwofa GE and Okwu QU, 2012. Studies on nutritive characteristics and variability in pawpaw (Carica papaya L.). Pakistan Journal of Nutrition 11 (10): 957-962

68. Lohiya, N.K., Pathak, N., Mishra, P.K., Manivannan, B., 2000. Contraceptive evaluation and toxicological study of aqueous extract of the seeds of C. papaya in male rabbits. Journal of Ethnopharmacology70,17-27.

69.

Goyal,S.,Manivannana,B.,Ansari,A.S.,Jainb,S.C.,Lohiya, N.K.,2010.Safety evaluation of long termoral treatment of methanol sub-fraction of the seeds of C. papaya as a male contraceptive in albino rats .Journal of Ethnopharmacology 127,286(-29).

70. Anuar, N.S., Zahari, S.S., Taib, I.A., Rahman, M.T., 2008. Effect of green and ripe C. papaya epicarp extracts on wound healing and during pregnancy. Foodand Chemical Toxicology46,2384-2389.

71. Abdulazeez, A., Mansurah, Ameh,D.A., Ibrahim,S., Ayo,J., Ambali, S.F., 2009.Effect of fermented and un fermented seed extracts of C. papaya on pre-implantation embryo development in female Wistar rats (Rattus norvegicus). Scientific ResearchandEssay4,1080-1084.

72. Stepek,G., Buttle, D.J., Duce, I.R., Lowe, A., Behnke, J.M., 2005.Assessment of the anthelmintic effect of natural plant cysteine proteinases against the gastrointestinal nematode, heligmosomoides polygyrus, in vitro. Parasitology130,203-211.

73. Otsuki, N., Dang, N.H., Kumagai, E., Kondo, A., Iwata, S., Morimoto ,C., 2010. Aqueous extract of C. papaya leaves exhibits anti-tumor activity and immune modulatory effects. JournalofEthnopharmacology127,760-767.

74. Wang, F., Xu, Z., Yuen, C.T., Chow, C.Y., Lui, Y.L., Tsang, S.Y., Xue, H., 2007. 6, 2-Dihydroxyflavone, a sub type-selective partial inverse agonist of GABAA
receptorbenzodiazepinesite.Neuropharmacology53,574582 .

74

Piccolo,V.K.,Mello,J.C.P.,deOliveira,R.M.W.,2010.

Dualeffectsof crude extracts obtained from Petiveriaalliacea L. (Phytolaccaceae) on experimental anxietyinmice. JournalofEthnopharmacology128,541544.

75.

Hajhashemi,V.,Rabbani,M.,Ghanadi,A.,Davari,E.,2010.E valuationofantianxiety and sedative effects of essential oil of Ducrosia anethifolia in mice.Clinics65, 1037-1042

76. Tovilović, G.,Krstić, D.,Ignjatović, D.,Janać, B.,Tomić, M.,2011. Anxiolytic-like effects of xanthonerich diethyl ether extract of Gentiana Kochiana in rodents. Digest JournalofNanomaterialsandBiostructures6,1385-1392.

77. Hewitt et al., 2000 Hong TD, Linington S, Ellis RH. 1996. Seed storage behaviour: a compendium. Handbooks for Genebanks: No. 4. IPGRI.

78. Bouanga-Kalou G, Nitou JG, Nzikou JM, Ganongo-Po FB, Hounounou CH, Diabangouaya B, Mpika-Bouesso J, Silou T, Desobry S, 2011. Physicochemical properties of oil extract from gumbo (Abelmoschus Esculentus L.) and the kinetics of degradation of the oil during heating. Aust J Basic Appl Sci 5(3):475-482

79. Cherian T, 2000. Effect of papaya latex extract on gravid and non gravid rat uterine preparation in vitro. $\mathrm{J}$ Ethnopharmacol. 70 suppl 2: 71-75

80. Adeneye AA and Olagunju JA, 2009. Preliminary hypoglicaemic and hypolipidaemic activities of aqueous seeds extract of Carica papaya L., in Wistar rats. boil and med. 1 suppl 1: 1-10

81. Latham, P., 2004. Useful plants of Bas-Congo province, Democratic Republic of the Congo. DFID, London, United Kingdom. 320 pp

82. Janick, J. \& Paull, R.E. (Editors), 2006. Encyclopedia of fruit and nuts. CABI, Wallingford, United Kingdom. 954 pp.

83. Taïta, P., 2000. La biodiversité des espèces spontanées utilisées dans l'alimentation et la pharmacopée dans la région de la réserve de biosphère de la Mare aux Hippopotames. In: Actes du Forum National de la Recherche Scientifique et des Innovations Technologiques (FRSIT), 3-8 avril 2000, Ouagadougou, Burkina Faso. Tome 2. Sécurité alimentaire. pp. 77-95.

84. Diallo D, SmestaB, Paulsen , Torun , 2001. Polysaccharides from the roots of Entada africana Guill. et Perr., Mimosaceae, with complement fixing activity Journal of Ethnopharmacology 74 (2001) 159-171

85. Pousset, J.-L., 2004. Planted médicinales d'Afrique. Comment les reconnaître et les utiliser? Edisud, Aix-enProvence, France. 287 pp.

86. Almela LB, Sanchez-Munoz JA, Fernandez-Lopez, Roca MJ, and Rabe V, 2006. Liquid chromatographic-mass sectrometric analysis of phenolics and free radical scavenging activity of rosemary extract from different raw material. J. Chromatogr. A, 1120: 221-229.

87. Tibiri A, Rakotonandrasana O, Nacoulma GO, and Banzouzi JT, 2007. Radical scavenging activity, phenolic content and cytottoxicity of bark and leaves extracts of Entada Africana Guill. and Perr. (Mimosaceae). Journal of Biological Sciences 7 (6): 959-963, 2007.

88. Mariani C, Braca A, Vitalini S, de Tommasi N, Visioli F, and Fico G, 2008. Flavonoid characterization and in vitro antioxidant activity of Aconitum anthora L. (Ranunculaceae). Phytochemistry, 69: 1220-1226

89. Abdel-Hameed ESSS, 2009. Total phenolic contents and free radical scavenging activity of certain Egyptian Ficus species leaf samples. food Chem., 114: 1271-1277 
90. Arcan I, and Yemenicioglu A, 2009. Antioxydant activity and phenolic content of fresh and dry nuts wit or without the seed coat. J. Food Comp. Anal., 22: 184-188.

91. Tibiri A, Sawadogo RW, Ouedraogo N, Banzuzi JT, Guissou IP, and Nacoulma GO, 2010. Evaluation of antioxidant activity, total phenolic and flavonoid contents of Entada Africana Guill. et Perr. (Mimosaceae) organ extracts. Research Journal of Medical Sciences 4 (2): 81 87.

92. Coffi G, Dal Piaz F, De Caprariis P, Sanogo R, and Marzocco S, 2006. Antiprolferative triterpene saponin from Entada African. J. Nat. Prod., 69: 1323-1329.

96. Silva, O., Barbosa, S., Diniz, A., Valdeira, L.M., Gomes, E., 1997. Plant extracts antiviral activity against Herpes simplex virus type I and African swine fever virus. International Journal of Ethnopharmacognosy 35, 12-16.

93. Bah, S., 1998. Sensibilite' d'Anopheles gambiae aux insecticides organiques de synthèse et a' divers extraits de plantes me'dicinales du Mali. The`se, Pharmacie, Bamako.

94. Atindehou, K.K., Schmid, C., Brun, R., Koné, M.W. \& Traoré, D., 2004. Antitrypanosomal and antiplasmodial activity of medicinal plants from Côte d'Ivoire. Journal of Ethnopharmacology 90(2): 221-227.

95. Koné, W.M., Atindehou, K.K., Terreaux, C., Hostettmann, K., Traoré, D. \& Dosso, M., 2004. Traditional medicine in North Côte d'Ivoire: screening of 50 medicinal plants for antibacterial activity. Journal of Ethnopharmacology 93(1): 43-49.

96. Sanogo, R., Germano, M.P., D’Angelo, V., Gugliemo, M., De Pasquale, R., 1998. Antihepatotoxic properties of Entada africana (Mimosaceae). Phytotherapy Research 12, S157-S159.

97. Inngjerdongen, K., Nergård, C.S., Diallo, D., Mounkoro, P.P. \& Paulsen, B.S., 2004. An ethnopharmacological survey of plants used for wound healing in Dogonland, Mali, West Africa. Journal of Ethnopharmacology 92: 233-244.

98. Nacoulma-Ouédraogo, O. \& Millogo-Rasolodimby, J., 2002. Les frotte-dents comme produits cosmétiques et médicinaux au Burkina Faso. Etudes de la flore et la végétation de Burkina Faso 7: 49-54.

99. FAO. 1986. Some medicinal plants of Africa and Latin America. FAO Forestry Paper. 67. Rome.

100. Katende $\mathrm{AB}$ et al. 1995. Useful trees and shrubs for Uganda. Identification, Propagation and Management for Agricultural and Pastoral Communities. Regional Soil Conservation Unit (RSCU), Swedish International Development Authority (SIDA).

101. Sosef MSM, Hong LT, Prawirohatmodjo S. (eds.). 1998. PROSEA 5(3) Timber trees: lesser known species. Backhuys Publishers, Leiden.

102. Vogt K. 1995. A field guide to the identification, propagation and uses of common trees and shrubs of dryland Sudan. SOS Sahel International (UK).

103. Caniato, R. \& Puricelli, L., 2003. Review: natural antimalarial agents (1995-2001). Critical Reviews in Plant Sciences 22(1): 79-105.

104. Zhang, H., Wang, X., Chen, F., Androulakis, X.M. \& Wargovich, M.J., 2007. Anticancer activity of limonoid from Khaya senegalensis. Phytotherapy Research 21(8): 731-734.

105. Androulakis, X.M., Muga, S.J., Chen, F., Koita, Y., Toure, B. \& Wargovich, M.J., 2006. Chemopreventive effects of Khaya senegalensis bark extract on human colorectal cancer. Anticancer Research 26(3B): 23972405.

106. Neuwinger, H.D., 1996. African ethnobotany: poisons and drugs. Chapman \& Hall, London, United Kingdom. 941 $\mathrm{pp}$

107. Potel A., 2002. Annuaire médiaphane.
108. Arnold, R., 2004. Khaya senegalensis: current use from its natural range and its potential in Sri Lanka and elsewhere in Asia. Paper presented at the Workshop Prospects for high-value hardwood timber plantations in the 'dry' tropics of northern Australia. 19-21 October 2004, Mareeba, Australia. 9 pp.

109. Neya, O., 2006. Conservation of tree seeds from tropical dry-lands. $\mathrm{PhD}$ thesis, Wageningen University, Wageningen, Netherlands. $160 \mathrm{pp}$

110. Karou, D., Dicko, M.H., Simpore, J. \& Traore, A.S., 2005. Antioxidant and antibacterial activities of polyphenols from ethnomedicinal plants of Burkina Faso. African Journal of Biotechnology 4(8): 823-828.

111. Ouattara L., J. Koudou, C. Zongo, N. Barro, A. Sawadogo, I.H.N. Bassole, A.S. Ouattara and A.S. Traore, 2011. Antioxidant and antibacterial activities of three species of Lannea from Burkina Faso. J. Appl. Sci., 11(2): 157-162.

112. Ajiboye TO, H.O.Rajib, H.F.Muritalac, O.B.Ojewuyia, M.T.Yakubuc. Food Bioscience 4 (2013) 58-67 Anthocyanin extract of Lannea microcarpa fruits stall oxidative rout associated with aflatoxin B1 hepatocarcinogenesis.

113. Duponchel, P., 2004. Textiles bògòlan du Mali. Collections du Mali No 8. Musée d'Ethnographie, Neuchâtel, Switzerland. 334 pp.

114. Nacoulma, O.G., 1996. Medicinal Plant and traditional practices in Burkina Faso: The case of the central plateau. Ph.D. Thesis in Natural Sciences, Vol. 1, 2.

115. Lamien-Meda, A., C.E. Lamien, M.M.Y. Compaoré, N.T. Meda, M. Kiendrebeogo, B. Zeba, J.F. Millogo and O.G. Nacoulma, 2008. Polyphenol Content and Antioxydant Activity of Fourteen Wild Edible Fruits from Burkina Faso. Molecules, ISSN 1420-8049.

116. Burkill, H.M., 2000. The useful plants of West Tropical Africa. 2nd Edition. Volume 5, Families S-Z, Addenda. Royal Botanic Gardens, Kew, Richmond, United Kingdom. 686 pp.

117. Picerno, P., T. Mencherini, R. Della-Loggia, M. Meloni and R. Sanogo, 2006. An extract of Lannea microcarpa: Composition, activity and evaluation of cutaneous irritation in cell cultures and reconstituted human epidermis. J. Pharm. Pharmacol., 58(7): 981-988.

118. Ouedraogo, S., L. Belemnaba, H. Zague, A. Traore, M. Lompo, I.P. Guissou, C. Lugnier and B. Bucher, 2010. Endothelium independent vasorelation by extract and Fractions from Lannea microcarpa Engl. and K. Krause (Anacardiaceae): Possible involvement of phosphodiesterase inhibition. Int. J.Phamacol. Biol. Sci., 4(2): 9-16

119. Pale, E., 1998. Contribution to the study of anthocyanin compounds in plants: The case of Hibicus sabdariffa, Lannea microcapa and Vigna sorghum caudatum from Burkina Faso. Graduate Thesis, University of Ouagadougou.

120. Grover JK, Yadav SP. Pharmacological actions and potential uses of Momordica charantia: a review. J Ethnopharmacol 2004; 93:123-132. Sarkar, S., Pranava, M., Marita, R., 1996. Demonstration of the hypoglycemic action of Momordica charantia in a validated animal model of diabetes. Pharmacology Research 33, 1-4.

121. Raman, A., Lau, C., 1996. Anti-diabetic properties and phytochemistry of Momordica charantia L. (Cucurbitaceae). Phytomedicine 2, 349-362.

129. Husain, J., Tickle, I.J., Wood, S.P., 1994. Crystal structure of momordin, a type I ribosome inactivating protein from the seeds of Momordica charantia. FEBS Letters 342, $154-158$

122. Xie, H., Huang, S., Deng, H., Wu, Z., Ji, A., 1998. Study on chemical components of Momordica charantia. Zhong Yao Cai. 21, 458-459 
131. Yuan, Y.R., He, Y.N., Xiong, J.P., Xia, Z.X., 1999. Three-dimensional structure of beta-momorcharin at 2.55 A resolution. Acta Crystallo

123. Parkash, A., Ng, T.B., Tso, W.W., 2002. Purification and characterization of charantin, a napin-like ribosomeinactivating peptide from bitter gourd (Momordica charantia) seeds. Journal of Peptide Research 59, 197202.

124. Murakami, T., Emoto, A., Matsuda, H., Yoshikawa, M., 2001. Medicinal foodstuffs. Part XXI. Structures of new cucurbitane-type triterpene glycosides, goyaglycosides-a, -b, -c, -d, -e, -f, -g, and -h, and new oleanane-type triterpene saponins, goyasaponins I, II, and III, from the fresh fruit of Japanese Momordica charantia L. Chemical \& Pharmaceutical Bulletin (Tokyo) 49, 54-63

125. Putnam, C.D., Tainer, J.A., 2000. The food of sweet and bitter fancy. Natural and Structural Biology 7, 17-18.

126. Jiratchariyakul, W., Wiwat, C., Vongsakul, M., Somanabandhu, A., Leelamanit, W., Fujii, I., Suwannaroj, N., Ebizuka, Y., 2001. HIV inhibitor from Thai bitter gourd. Planta Medica 67, 350-353.

127. Wang, H.X., Ng, T.B., 2001a. Examination of lectins, polysaccharopeptide, polysaccharide, alkaloid, coumarin and trypsin inhibitors for inhibitory activity against human immunodeficiency virus reverse transcriptase and glycohydrolases. Planta Medica 67, 669-672.

128. Hamato, N., Koshiba, T., Pham, T.N., Tatsumi, Y., Nakamura, D., Takano, R., Hayashi, K., Hong, Y.M., Hara, S., 1995. Trypsin and elastase inhibitors from bitter gourd (Momordica charantia LINN.) seeds: purification, amino acid sequences, and inhibitory activities of four new inhibitors. Journal of Biochemistry (Tokyo) 117, 432-437.

129. Chakraborty, S., Bhattacharya, S., Ghosh, S., Bera, A.K., Haldar, U., Pal, A.K., Mukhopadhyay, B.P., Banerjee, A., 2000. Structural and interactional homology of clinically potential trypsin inhibitors: molecular modelling of cucurbitaceae family peptides using the X-ray structure of MCTI-II. Protein Engineering 13, 551-555.

130. Takemoto, D.J., Kresie, R., Vaughn, D., 1980. Partial purification and characterization of a guanylate cyclase inhibitor with cytotoxic properties from the bitter melon (Momordica charantia). Biochemical Biophysical Research Communictions 94, 332-339.

131. Matsuur, H., Asakawa, C., Kurimoto, M., Mizutani, J., 2002. Alphaglucosidase inhibitor from the seeds of balsam pear (Momordica charantia) and the fruit bodies of Grifola frondosa. Bioscience Biotechnology and Biochemistry 66, 1576-1578.

132. Ahmed, I., Adeghate, E., Sharma, A.K., Pallot, D.J., Singh, J., 1998. Effects of Momordica charantia fruit juice on islet morphology in the pancreas of the streptozotocin-diabetic rat. Diabetes Research Clinical Practices 40, 145-151.

133. Sitasawad, S.L., Shewade, Y., Bhonde, R., 2000. Role of bittergourd fruit juice in stz-induced diabetic state in vivo and in vitro. Journal of Ethnopharmacology 73, 71-79.

134. Ahmed, I., Lakhani, M.S., Gillett, M., John, A., Raza, H., 2001. Hypotriglyceridemic and hypocholesterolemic effects of anti-diabetic Momordica charantia (karela) fruit extract in streptozotocin-induced diabetic rats. Diabetes Research Clinical Practices 51, 155-161.

135. Miura, T., Itoh, C., Iwamoto, N., Kato, M., Kawai, M., Park, S.R., Suzuki, I., 2001. Hypoglycemic activity of the fruit of the Momordica charantia in type 2 diabetic mice. Journal of Nutrition Sciences Vitaminology (Tokyo) 47, $340-344$.

136. Grover, J.K., Rathi, S.S., Vats, V., 2002. Amelioration of experimental diabetic neuropathy and gastropathy in rats following oral administration of plant (Eugenia jambolana, Mucuna pruriens and Tinospora cordifolia) extracts. Indian Journal of Experimental Biology 40, 273276.

137. Rathi, S.S., Grover, J.K., Vats, V., 2002a. The effect of Momordica charantia and Mucuna pruriens in experimental diabetes and their effect on key metabolic enzymes involved in carbohydrate metabolism. Phytotherapy Research 16, 236-243.

138. Rathi, S.S., Grover, J.K., Vikrant, V., Biswas, N.R., 2002b. Prevention of experimental diabetic cataract by Indian Ayurvedic plant extracts. Phytotherapy Research $16,774-777$

139. Khan, M.R., et al., 1998. Momordica charantia and Allium sativum: broadspectrum antibacterial activity. Korean Journal of Pharmacognosy 29, 155-158.

140. Omoregbe, R.E., Ikuebe, O.M., Ihimire, I.G., 1996. Antimicrobial activity of some medicinal plants extracts on Escherichia coli, Salmonella paratyphi and Shigella dysenteriae. African Journal of Medical Science 25, 373375.

141. Yesilada, E., Gurbuz, I., Shibata, H., 1999. Screening of Turkish antiulcerogenic folk remedies for antiHelicobacter pylori activity. Journal of Ethnopharmacology 66, 289-293.

142. Frame, A.D., Rios-Olivares, E., De Jesus, L., Ortiz, D., Pagan, J., Mendez, S., 1998. Plants from Puerto Rico with anti-Mycobacterium tuberculosis properties. Puerto Rico Health Science Journal 17, 243-252.

143. Zheng, Y.T., Ben, K.L., Jin, S.W., 1999. Alphamomorcharin inhibits HIV- 1 replication in acutely but not chronically infected T-lymphocytes. Zhongguo Yao Li Xue Bao 20, 239-243.

144. Au, T.K., Collins, R.A., Lam, T.L., Ng, T.B., Fong, W.P., Wan, D.C., 2000. The plant ribosome inactivating proteins luffin and saporin are potent inhibitors of HIV-1 integrase. FEBS Letters 471, 169-172.

154. Battelli, M.G., Polito, L., Bolognesi, A., Lafleur, L., Fradet, Y., Stirpe, F., 1996. Toxicity of ribosomeinactivating proteins-containing immunotoxins to a human bladder carcinoma cell line. International Journal of Cancer 68, 485-490.

145. Kusamran, W.R., Ratanavila, A., Tepsuwan, A., 1998. Effects of neem flowers, Thai and Chinese bitter gourd fruits and sweet basil leaves on hepatic monooxygenases and glutathione $S$-transferase activities, and in vitro metabolic activation of chemical carcinogens in rats. Food and Chemical Toxicology 36, 475-484.

146. Ganguly, C., De, S., Das, S., 2000. Prevention of carcinogen-induced mouse skin papilloma by whole fruit aqueous extract of Momordica charantia. European Journal of Cancer Prevention 9, 283-288.

147. Sun, Y., Huang, P.L., Li, J.J., Huang, Y.Q., Zhang, L., Huang, P.L., Lee-Huang, S., 2001. Anti-HIV agent MAP30 modulates the expression profile of viral and cellular genes for proliferation and apoptosis in AIDSrelated lymphoma cells infected with Kaposi's sarcomaassociated virus. Biochemical and Biophysical Research Communication 287, 983-994

148. Basch, E., Gabardi, S., Ulbricht, C., 2003. Bitter melon (Momordica charantia): a review of efficacy and safety. American Journal of Health and Systemic Pharmacology 65, 356-359.

149. Naseem, M.Z., Patil, S.R., Patil, S.R., Ravindra-Patil, R.S., 1998. Antispermatogenic and androgenic activities of Momordica charantia (karela) in albino rats. Journal of Ethnopharmacology 61, 9-16.

150. Schreiber, C.A., Wan, L., Sun, Y., Lu, L., Krey, L.C., Lee-Huang, S., 1999. The antiviral agents, MAP30 and GAP31, are not toxic to human spermatozoa and may be useful in preventing the sexual transmission of human immunodeficiency virus type 1 . Fertility and Sterility 72 , 686-690. 
151. Matsuda, H., Li, Y., Yoshikawa, M., 1999. Roles of capsaicin-sensitive sensory nerves, endogenous nitric oxide, sulfhydryls, and prostaglandins in gastroprotection by momordin Ic, an oleanolic acid oligoglycoside, on ethanol-induced gastric mucosal lesions in rats. Life Science 65, PL27-PL32.

152. Gurbuz, I., Akyuz, C., Yesilada, E., Sener, B., 2000. Antiulcerogenic effect of Momordica charantia L. fruits on various ulcer models in rats. Journal of Ethnopharmacology 7, 77-82.

153. Lal, J., Chandra, S., Raviprakash, V., Sabir, M., 1976. In vitro anthelmintic action of some indigenous medicinal plants on Ascardia galli worms. Indian Journal of Physiology and Pharmacology 20, 64-68.

154. Munoz, V., Sauvain, M., Bourdy, G., Callapa, J., Rojas, I., Vargas, L., Tae, A., Deharo, E., 2000. The search for natural bioactive compounds through a multidisciplinary approach in Bolivia. Part II. Antimalarial activity of some plants used by Mosetene indians. Journal of Ethnopharmacology 69, 139-155.

155. Kohler, I., Jenett-Siems, K., Siems, K., Hernandez, M.A., Ibarra, R.A., Berendsohn, W.G., Bienzle, U., Eich, E., 2002. In vitro antiplasmodial investigation of medicinal plants from El Salvador. Zeitschrift fur Naturforschung [section-C]. 57, 277-281.

156. Biswas, A.R., Ramaswamy, S., Bapna, J.S., 1991. Analgesic effect of Momordica charantia seed extract in mice and rats. Journal of Ethnopharmacology 31, 115118.

157. Choi, J., Lee, K.T., Jung, H., Park, H.S., Park, H.J., 2002. Anti-rheumatoid arthritis effect of the Kochia scoparia fruits and activity comparison of momordin Ic, its prosapogenin and sapogenin. Archives of Pharmacological Research 25, 336-342.

158. Assubaie NF and El-Garaxany MM, 2004. Evaluation of some important chemical constituents of Momordica charantia cultivated in Hofuf, Saudi Arabia. Journal of Biological Sciences, 4(5): 628-630

159. Ahmad Z, Zamhuri KF, Yaacob A, Siong CH, Selvarajah M, Ismail A and Hakim MN, 2012. In Vitro Antidiabetic Activities and Chemical Analysis of Polypeptide$\mathrm{k}$ and Oil Isolated from Seeds of Momordica charantia (Bitter Gourd). Molecules, 17, 9631-9640

160. von Maydell, H.J. 1983. Arbes et arbustes du Sahel. Leurs caractéristiques et leurs utilisations. Eschnorn, GTZ. 531 p.

161. ICRAF. 1997. Annual Report 1996. ICRAF, Nairobi, Kenya. 340 p.

162. Abreu, P.M., Martins, E.S., Kayser, O., Bindseil, K.-U., Siems, K., Seemann, A. \& Frevert, J., 1999. Antimicrobial, antitumor and antileishmania screening of medicinal plants from Guinea-Bissau. Phytomedicine 6(3): 187-195.

163. Diallo, D., Sogn, C., Samaké, F.B., Paulsen, B.S., Michaelsen, T. E. \& Keita, A., 2002. Wound healing plants in Mali, the Bamako Region: an ethnobotanical survey and complement fixation of water extracts from selected plants. Pharmaceutical Biology 40(2): 117-128.

164. Roussel, J. 1996. Pépinière et plantations forestières en Afrique tropicale sèche. ISRA/CIRAD, Dakar, Senegal. $435 \mathrm{p}$.

165. CAB International, 2005. Forestry Compendium. Pterocarpus erinaceus. [Internet] http://www.cabicompendium.org/ fc/datasheet.asp?ccode=pteler. Accessed June 2007.

166. Akpalu, B.M., 1998. A preliminary study of the nutritive value of Pterocarpus erinaceus, a leguminous browse plant. BSc. Botany degree thesis, Department of Botany, Faculty of Science, University of Cape Coast, Cape Coast, Ghana. 34 pp.
167. Morton, J. (1987). Tamarind. In: Fruits of warm climates, Morton, J.F. (ed.). Miami, USA, p. 115-121.

168. Havinga, R. M., Hartl, A. H., Putscher, J., Prehsler, S., Buchmann, C., \& Vogl, C. R. (2010). Tamarindus indica L. (Fabaceae): Patterns of use in traditional African medicine. Journal of Ethnopharmacology, 127, 573-588. http://dx.doi.org/10.1016/j.jep.2009.11.028

169. Glew, R.S., VanderJagt, D.J., Chuang, L.T., Huang, Y.S., Millson, M., Glew, R.H. (2005). Nutrient content of four edible wild plants from West Africa. Plant Foods for Human Nutrition, 60, 187-193.

170. El-Siddig, K., Ebert, G., Lüdders, P. (1999). Tamarind (Tamarindus indica L.): a Review on a Multipurpose Tree with Promising Future in the Sudan. Journal of Applied Botany - Angewandte Botanik, 73, 202-205.

171. Ajayi, I.A., Oderinde, R.A., Kajogbola, D.O., Uponi, J.I. (2006). Oil content and fatty acid composition of some underutilized legumes from Nigeria. Food Chemistry, 99, 115-120.

172. Doughari, J.H., 2006. Antimicrobial activity of Tamarindus indica Linn. Tropical Journal of Pharmaceutical Research 5, 597-603.

173. Fandohan, A.B., 2007. Structure des populations et importance socio-culturelle du tamarinier (Tamarindus indica L.) dans la commune de Karimama (Bénin). Faculté des Sciences Agronomiques, Université d'Abomey-Calavi (UAC), Bénin, Abomey-Calavi, Bénin, p. 60 .

174. Norscia, I., Borgognini-Tarli, S.M., 2006. Ethnobotanical reputation of plant species from two forests of Madagascar: A preliminary investigation. South African Journal of Botany 72, 656-660.

175. Geissler, P.W., Harris, S.A., Prince, R.J., Olsen, A., Odhiambo, R.A., Oketch-Rabah, H., Madiega, P.A., Andersen, A., Molgaard, P., 2002. Medicinal plants used by Luo mothers and children in Bondo district, Kenya. Journal of Ethnopharmacology 83, 39-54.

176. Kristensen, M., Balslev, H., 2003. Perceptions, use and availability of woody plants among the Gourounsi in Burkina Faso. Biodiversity and Conservation 12, 17151739 .

177. Maiti, R., Jana, D., Das, U. K., \& Ghosh, D. (2004). Antidiabitic effect of aqueous extract of seed of Tamarindus indica in streptozontocin-induced diabetic rats. Journal of Ethnopharmacology, 92, 85-91. http://dx.doi.org/10.1016/j.jep.2004.02.002

178. El-Siddig, K., Gunasena, H.P.M., Prasad, B.A., Pushpakumara, D.K.N.G., Ramana, K.V.R., Vijayanand, P., Williams, J.T., 2006. Tamarind. Tamarindus indica L. International Centre for Underutilised Crops, University of Southampton, SO17 1BJ, UK, Southampton.

179. Baldé, N., Youlaa, A., Baldé, M.D., Kakéa, A., Dialloa, M.M., Baldé, M.A., Maugendred, D., 2006. Herbal medicine and treatment of diabetes in Africa: an example from Guinea. Diabetes \& Metabolism 32, 171-175.

180. Ahua, K.M., Ioset, J.-R., Ioset, K.N., Diallo, D., Mauel, J., Hostettmann, K., 2007. Antileishmanial activities associated with plants used in the Malian traditional medicine. Journal of Ethnopharmacology 110, 99104.

181. Alawa, J.P., Jokthan, G.E., Akut, K., 2002. Ethnoveterinary medical practice for ruminants in the subhumid zone of northern Nigeria. Preventive Veterinary Medicine 54, 79-90.

182. Asase, A., Oteng-Yeboah, A.A., Odamtten, G.T., Simmonds, M.S.J., 2005. Ethnobotanical study of some Ghanaian anti-malarial plants. Journal of Ethnopharmacology 99, 273-279.

183. Makundi, E.A., Malebo, H.M., Mhame, P., Kitua, A.Y., Warsame, M., 2006. Role of traditional healers in the management of severe malaria among children below five 
years of age: the case of Kilosa and Handeni Districts, Tanzania. Malaria Journal 5, 58.

184. Tabuti, J.R.S., 2008. Herbal medicines used in the treatment of malaria in Budiope county, Uganda. Journal of Ethnopharmacology 116, 33-42.

185. Hewlett, B.S., Cline, B.L., 2001. Anthropological Contributions to a Community-Based Schistosomiasis. Control Project in Northern Cameroon. Washington State University, Vancouver.

186. Inngjerdingen, K., Nergard, C.S., Diallo, D., Mounkoro, P.P., Paulsen, B.S., 2004. An

ethnopharmacological survey of plants used for wound healing in Dogonland,

Mali, West Africa. Journal of Ethnopharmacology 92, 233244.

187. Bah, S., Diallo, D., Dembele, S., Paulsen, B.S., 2006. Ethnopharmacological survey of plants used for the treatment of schistosomiasis in Niono District, Mali. Journal of Ethnopharmacology 105, 387-399.

188. Magassouba, F.B., Diallo, A., Kouyaté, M., Mara, F., Mara, O., Bangoura, O., Camara, A., Traoré, S., Diallo, A.K., Zaoro, M., Lamah, K., Diallo, S., Camara, G., Traoré, S., Kéita, A., Camara, M.K., Barry, R., Kéita, S., Oularé, K., Barry, M.S., Donzo, M., Camara, K., Toté, K., Vanden Berghe, D., Totté, J., Pieters, L., Vlietinck, A.J., Baldé, A.M., 2007. Ethnobotanical survey and antibacterial activity of some plants used in Guinean traditional medicine. Journal of Ethnopharmacology 144, 44-53.

189. Abdu, P.A., Jagun, A.G., Gefu, J.O., Mohammed, A.K., Alawa, C.B.I., Omokanye, A.T., 2000. A survey of ethnoveterinary practices of agropastoralists in Nigeria. In: Gefu, J.O., Abdu, P.A., Alawa, C.B.I. (Eds.), Ethnoveterinary Practices, Research and Development. National Animal Production Research Institute,AhmaduBello University, Zaria, Nigeria, pp. 2537 (Cited in Useh et al., 2006).

190. Useh, N.M., Nok, A.J., Esievo, K.A.N., 2006. Blackleg in ruminants. $\mathrm{CAB}$ Reviews: Perspectives in Agriculture, Veterinary Science, Nutrition and Natural Resources 1, 8.

191. Atawodi, S.E., Ameh, D.A., Ibrahim, S., Andrew, J.N., Nzelibe, H.C., Onyike, E.O., Anigo, K.M., Abu, E.A., James, D.B., Njoku, G.C., Sallau, A.B., 2002. Indigenous knowledge system for treatment of trypanosomiasis in Kaduna state of Nigeria. Journal of Ethnopharmacology $79,279-282$

192. Tabuti, J.R.S., Lye, K.A., Dhillion, S.S., 2003. Traditional herbal drugs of Bulamogi, Uganda: plants, use and administration. Journal of Ethnopharmacology 88, 19-44.

193. Kumar, C.S.; Bhattacharya, S. Tamarind Seed: Properties, Processing and Utilization. Critical Reviews in Food Science and Nutrition. 2008, 48, 1-20.

193. ICRAF. 2007. Agroforestry tree database (CD ROM). ICRAF, Nairobi.

194. Nordeide, M.B., Hatloy, A., Oshaug, A., Folling, M., Lied, E., 1996. Nutrient composition and nutritional importance of green leaves and wild food resources in an agricultural district, Koutiala, in Southern Mali. International Journal of Food Sciences and Nutrition 47, 455-468. 